\title{
LOCAL OPINION LEADERS KNOWLEDGE CONCERNING THE DAMAGED OF THE IRRIGATION BY UNTREATED DRAINAGE WATER AND THE CONTROLLING PRACTICES IN KAFR EL- SHEIKH GOVERNORATE
}

\author{
MOHAMED ABD EL- FATTAH ESSAYED
}

Agricultural Extension and Rural Development Research Institute- ARC, Giza

(Manuscript received 4 September 2016)

\begin{abstract}
T his research aimed at determining the knowledge level of agricultural local opinion leaders concerning the damages of irrigation by untreated drainage water, and the suggestions of agricultural extension workers for controlling these practices. Three villages were selected randomly in sedy sallem district. A sample of 206 opinions local leaders were determined by key informants. Frequencies, percentages, arithmetic mean, and standard deviation were used for presenting results.

The most important results could be summarized as follows:

1 - $(73 \%)$ of respondents used agricultural drainage water in the irrigation process, $(18 \%)$ of them used mixed water and about ( $9 \%$ ) of them irrigated with fresh water.

2- The knowledge level of $(79 \%)$ of the total respondents with damages of irrigation with

3- The most important suggestion for controlling the damages resulting from using drainage water were as follows : conducting training workshops regarding the disadvantages of using drainage water, providing farmers with recommendations for correct irrigation and
\end{abstract} drainage water was high. activating the role of agricultural extension. 


\section{معارف قادة الرأى الزراعيين المحليين بأضر ار الري بمياه الصرف الزراعي غير المعالجة وممارسات الحد منها بمحافظة كفر الثيخ}

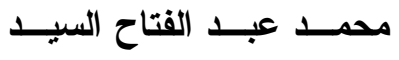

معهر بحوث الإرشاد الزراعي والتتمية الريفية- مركز البحوث الزراعية

\section{المستخلـــ}

استهدف هذا البحث بصفة رئيسية تحديد مستوى معرفة قادة الــر أى

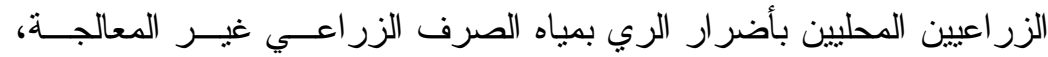

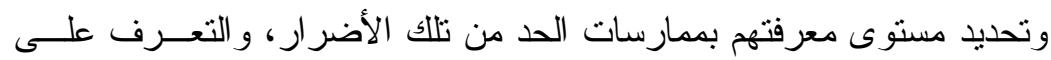

وجهات نظر هم فيما يجب أن يقوم به الإرشاد الزر اعى للحد من تلأك الأضر ار بار

ببعض قرى مركز سيدي سالم بمحافظة كفر الثنيخ، حيث تم اختيار ثناث قرى الإن

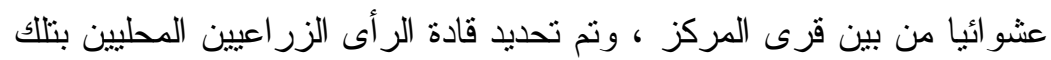

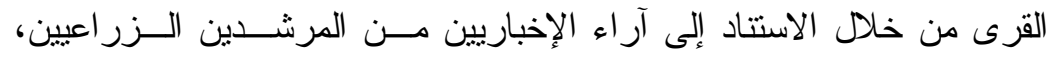

ومديري الجمعيات التعاونية الزر اعية، ومسئول المركز الإرشادي، ومســئول الإسئل

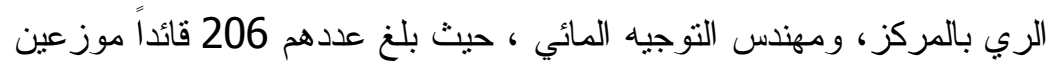

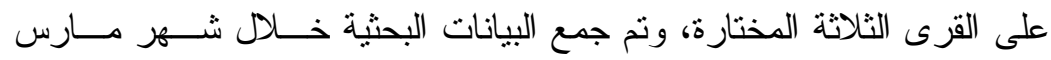

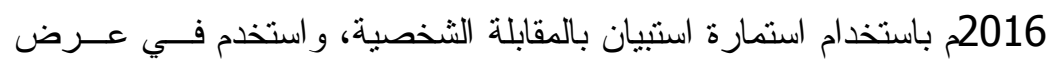

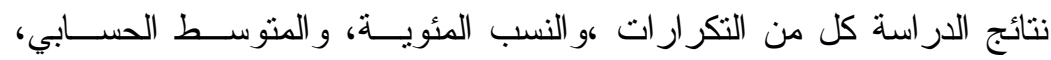

و الانحر اف المعياري.

وتمثلت أبرز النتائج فيما يلي :

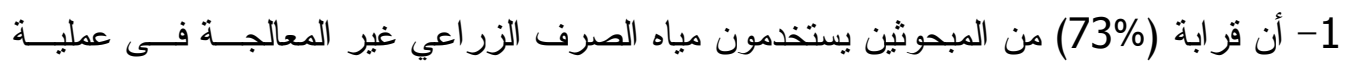

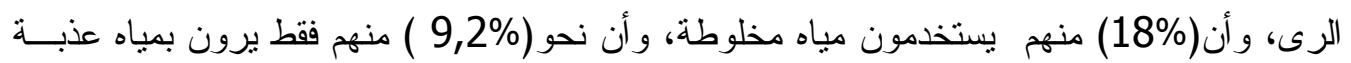

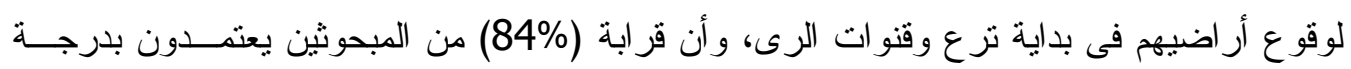

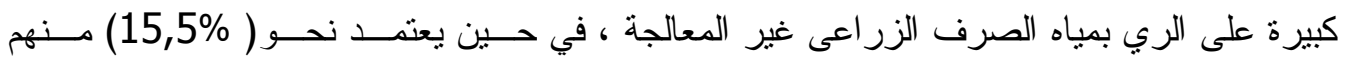

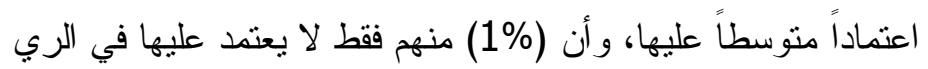

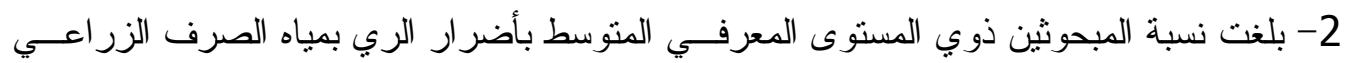
غير المعالجة ( 21,4\% ) من إجمالي المبحوثين.

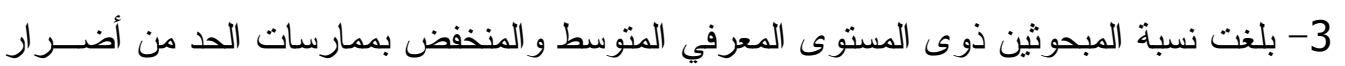
الري بمياه الصرف الزر اعي غير المعالجة (45,63 \% من إجمالي المبحوثين.

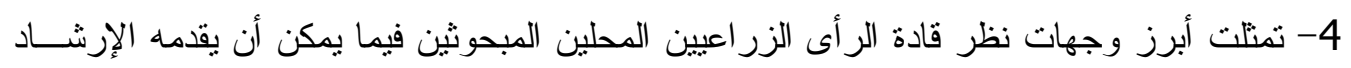

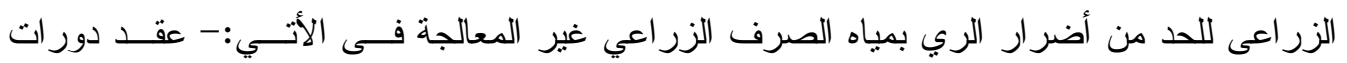


تدريبية للتوعية بأضرار الرى بمياه الصرف الزر اعي غير المعالجــة( 89,8\%)، وإمــــاد الــزراع

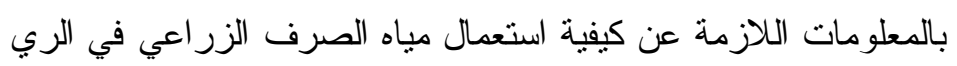

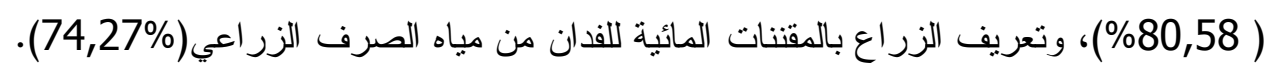

\section{مقدمة ومثكلة البحث}

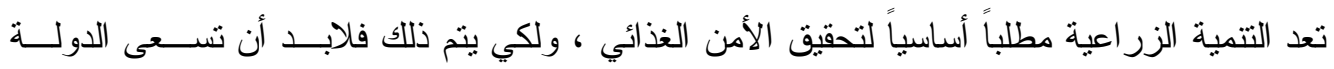

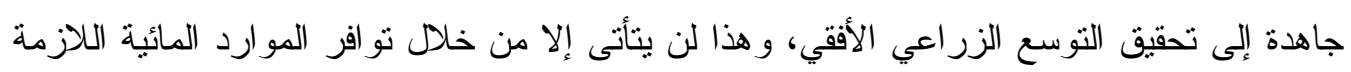

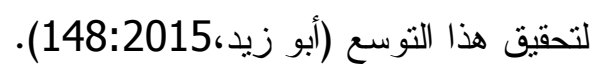

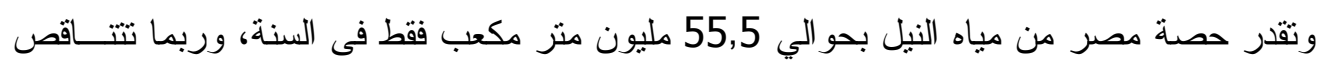
هذه الحصة من المياه مستقبلا نتيجة إقامة مشروعات السدود في دول دئ أعالي النيل.

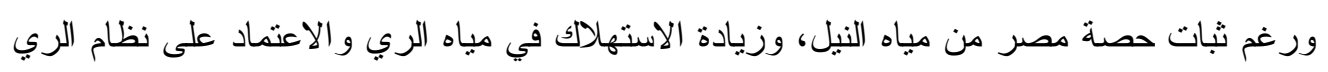

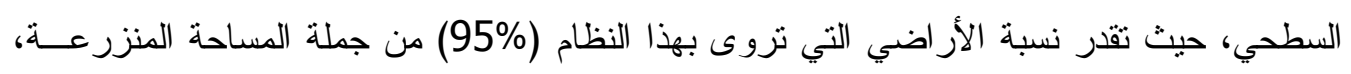

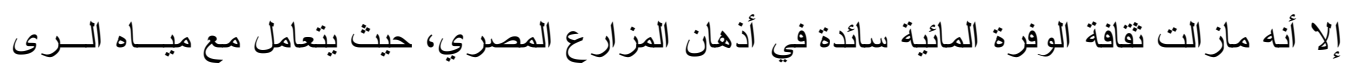

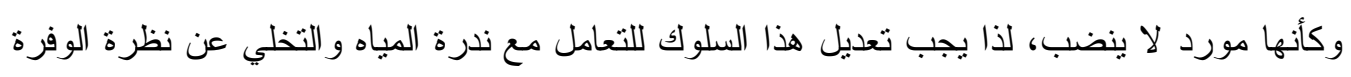
المائية (إسماعيل، 2013 : 78).

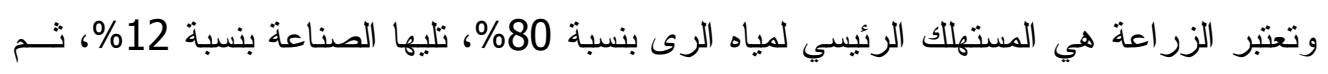

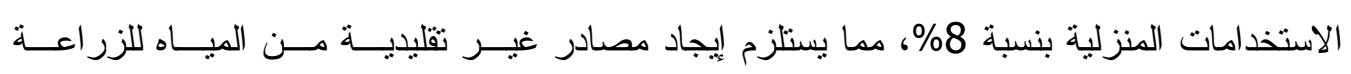

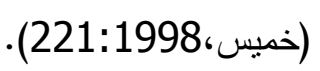

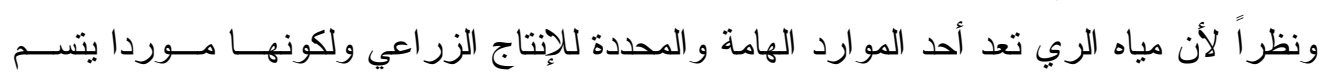

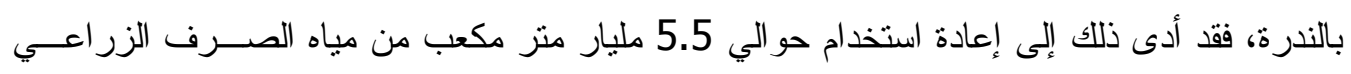

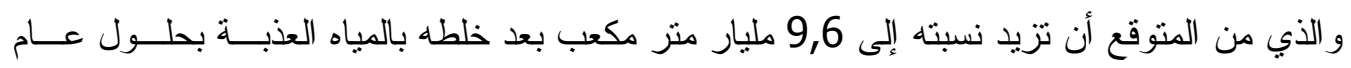
.(Allam,2007:83) 2017

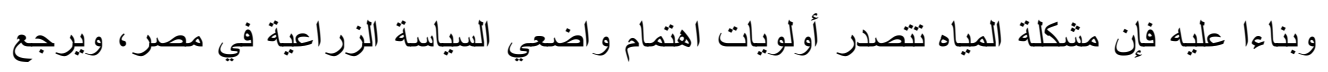

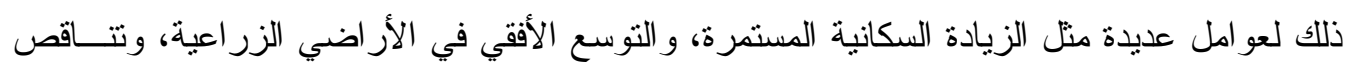

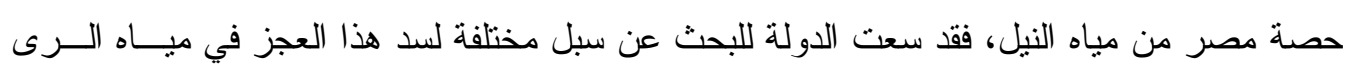

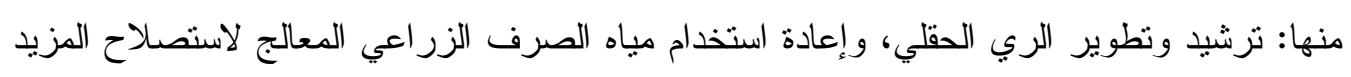

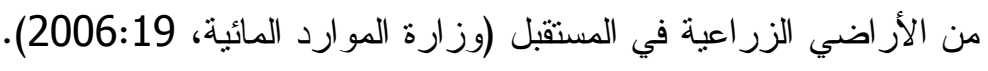

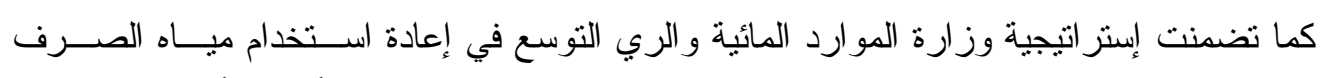
الزراعي في الري، ومن أجل ذلك أصبحت مياه الصرف الزر اعي تمثل جانباً أساسياً للسياسة المائية

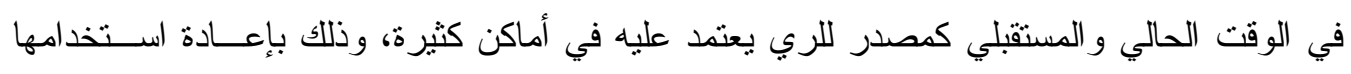

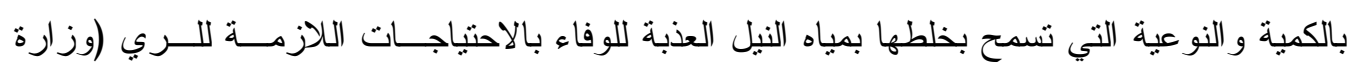

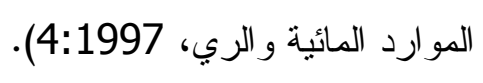
هذا ويحيط باستخدام مياه الصرف الزراعي غير المعالجة فى عملية الري مشكلات عديدة لابد من

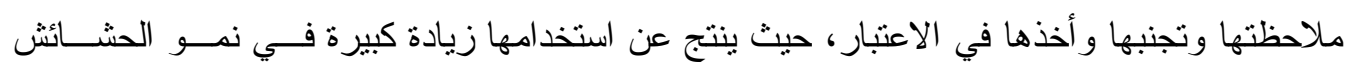


بالأر اضي التي تروى بها، كما أن زيادة نسبة الأملاح بها يؤثز على خصوبة التزبة تــأثثر اً مباثـــــاً

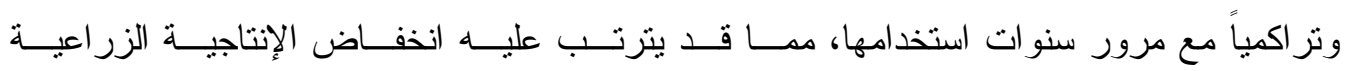

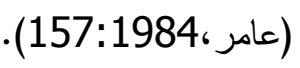
وبالإضافة لما سبق فإن مياه الصرف الزر اعي غير المعالجة تحتوى على بقايا مبيــدات و أســـدة

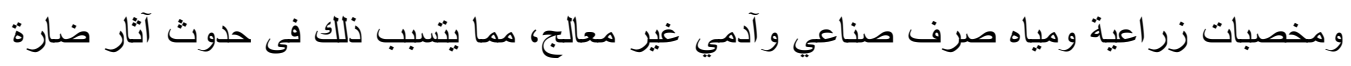
على خصوبة الأرض الزر اعية وصحة الإنسان و الحيوان.(Abd- El-Naim et al., 1982:73).

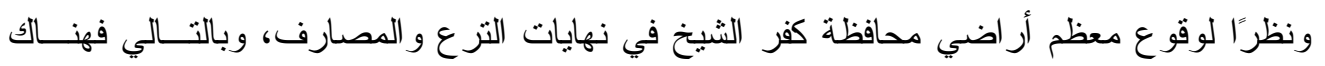

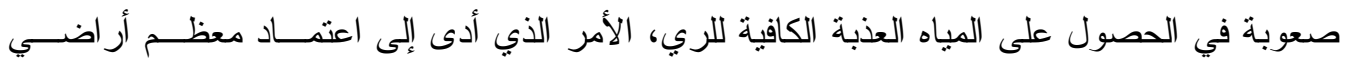

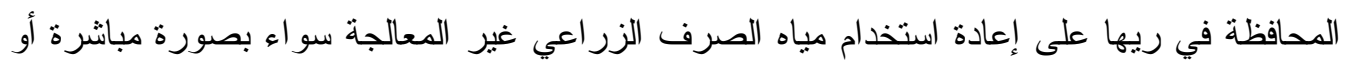

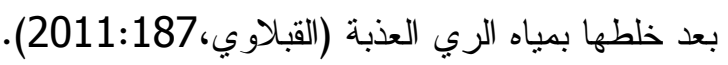
وتتمتل مصادر مياه الرى بمحافظة كفر الثيخ التى تتنتمل على عشر مر اكز إدارية فى مصــدرين

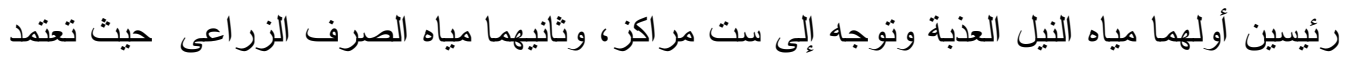

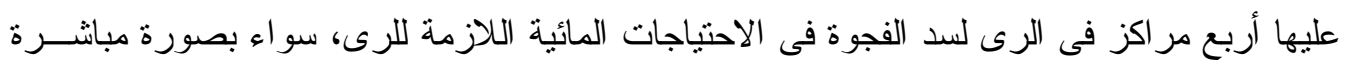

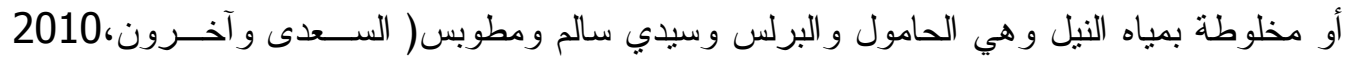
.(197: وتقدر مساحة الأرض الزر اعية بمحافظة كفر الثيخ التي تشتخدم مياه الصــرف الزر اعـي غيــر

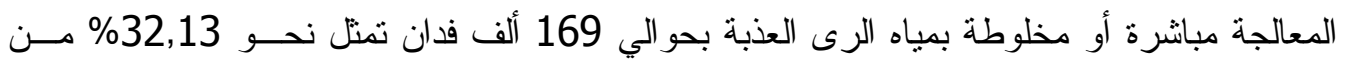

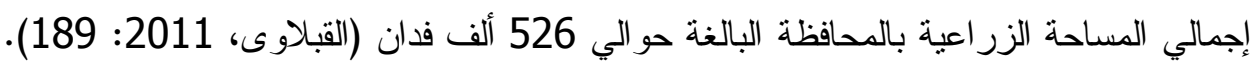

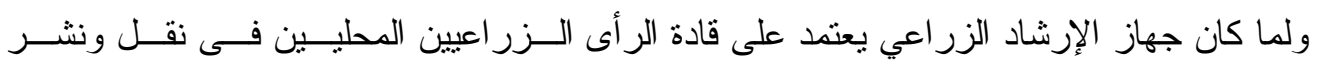

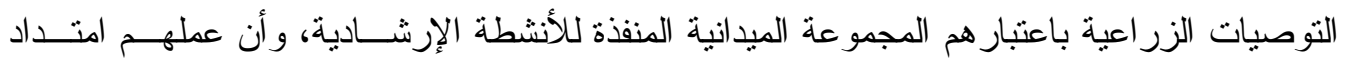

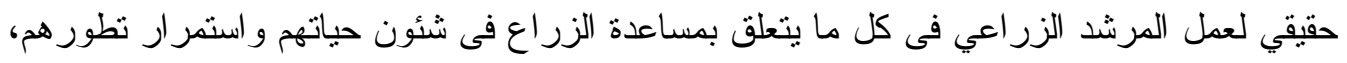

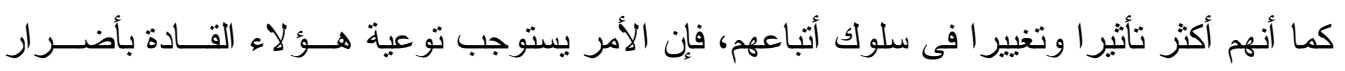

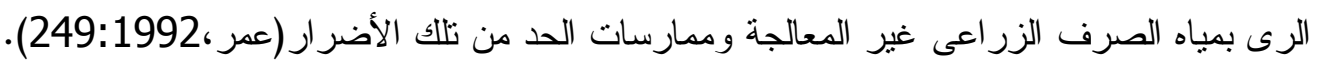

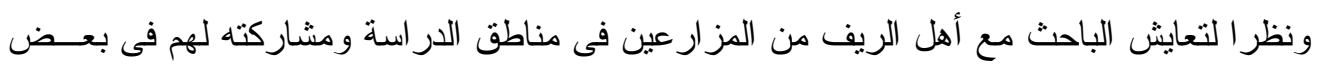

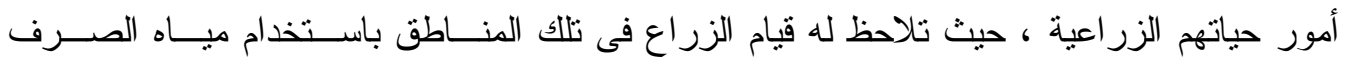

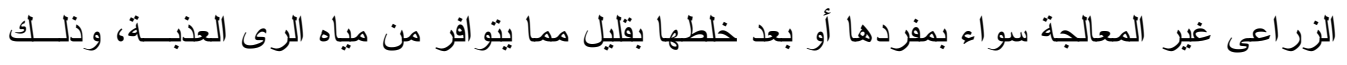

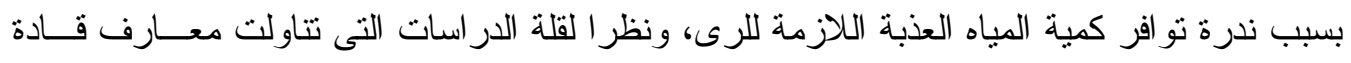

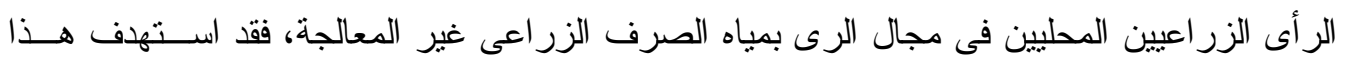

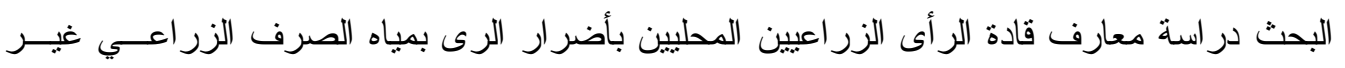

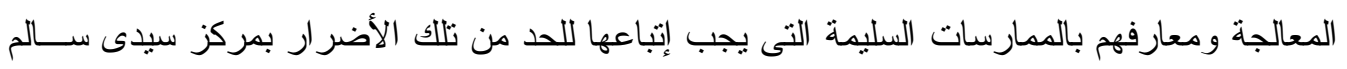

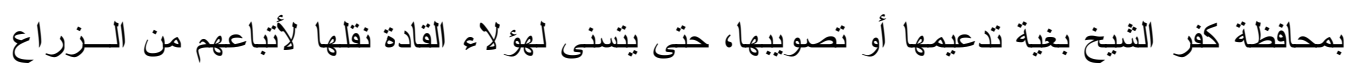




\section{أهـــاف البحــث}

استهدف هذا البحث بصفة رئيسية الوقوف على معارف قادة الرأى الزر اعيين المحليين بأضــرار

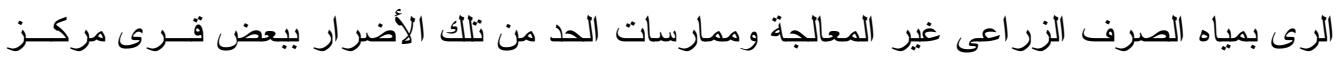

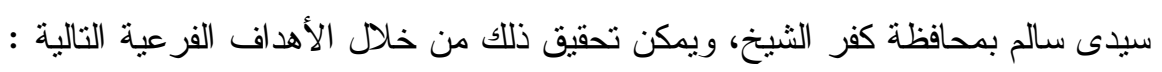

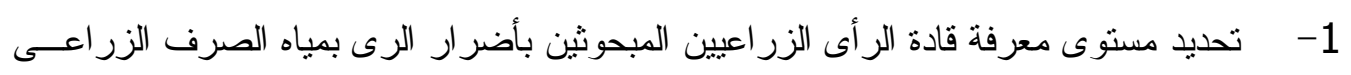

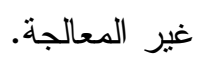
2- تحديد مستوى معرفة قادة الر أى الزر اعيين المبحوثين بالممارسات التى يجب إنباعها للحد من أضرار الرى بمياه الصرف الزر اعى غير المعالجة .

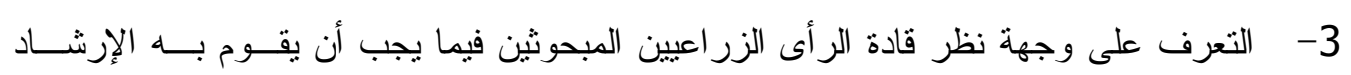

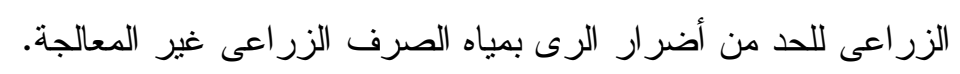

\section{الاستعر اض المرجعي}

تعتبر نظرية التعلم الاجتماعي (لروتر Rotter) أساساً نظرياً لهذا البحث، حيث برى أن كثير من فئن

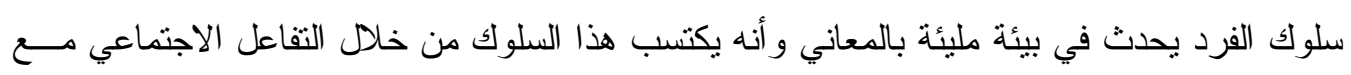

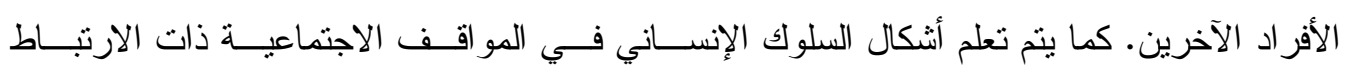

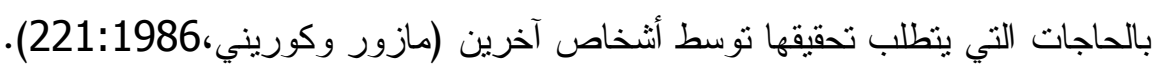

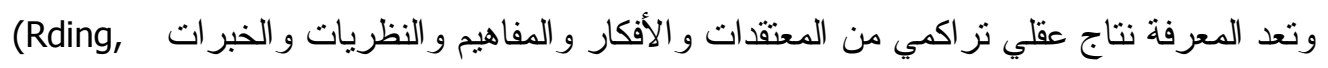

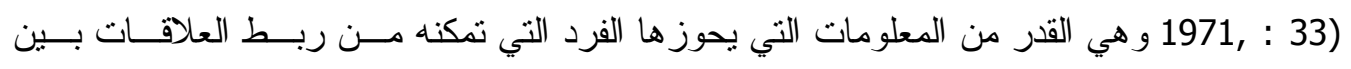

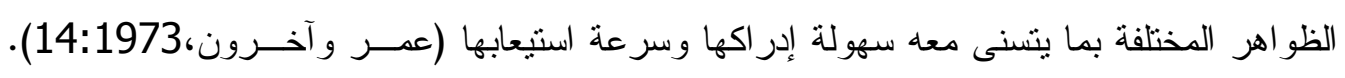

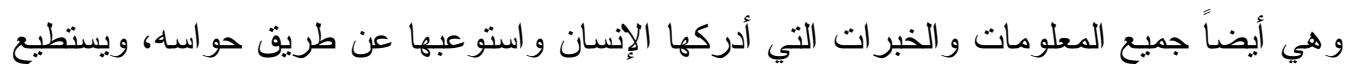

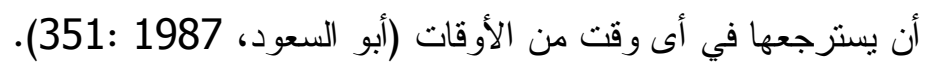

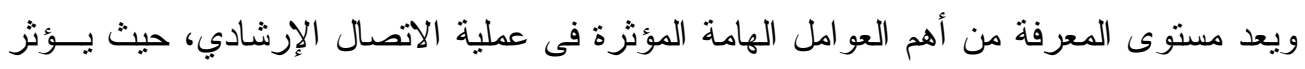

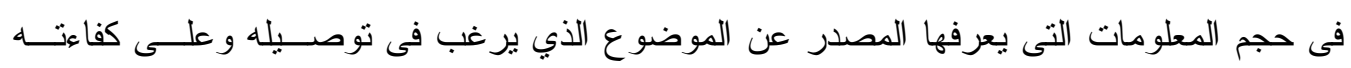
الاتصالية ( عبد المقصود،1988 :190).

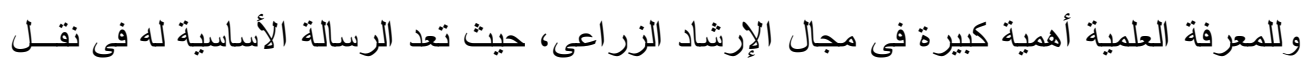

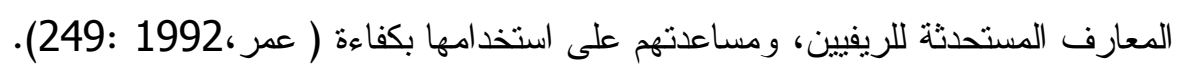

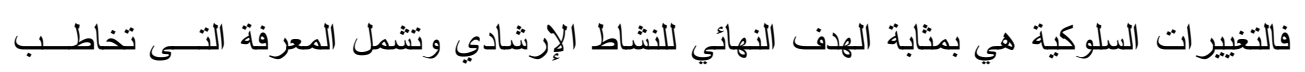

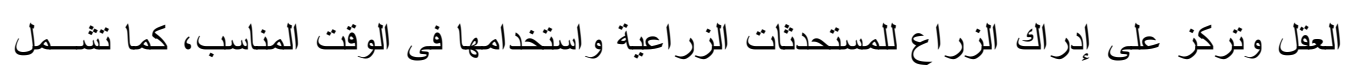

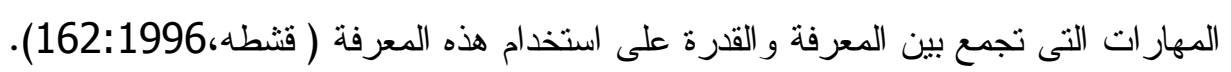

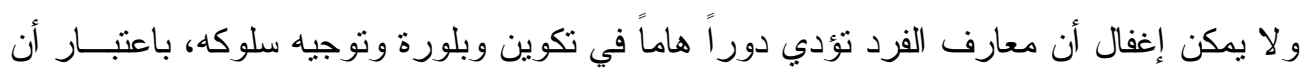

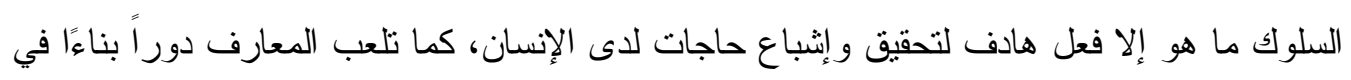

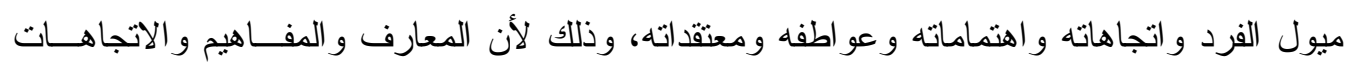

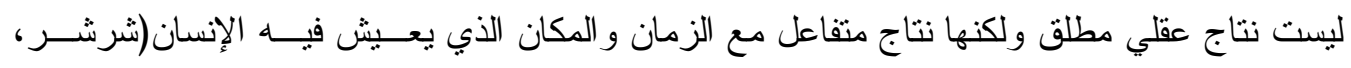




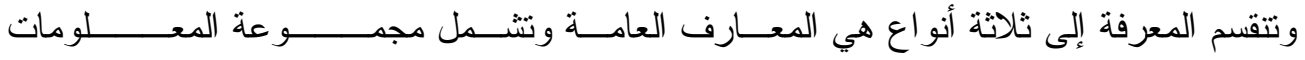

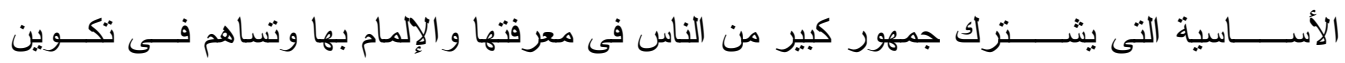

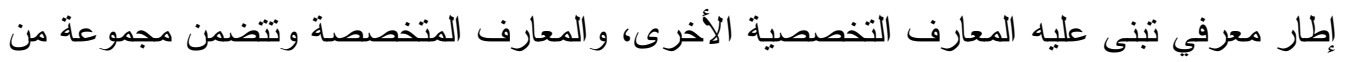

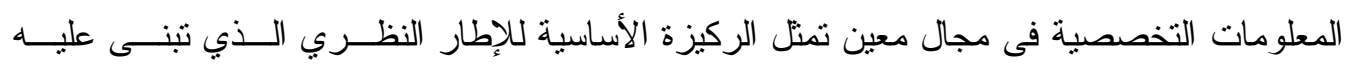
التطبيقات المهنية الأخرى، والمعارف المهنية وتتشمل مجموعة من المعلومات ذات الطبيعة التطبيقية

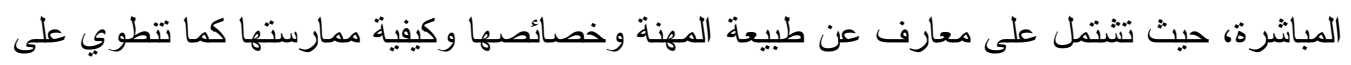

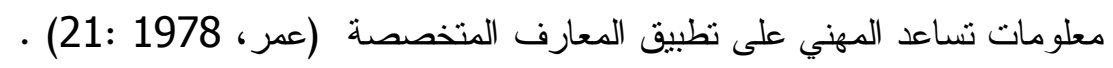

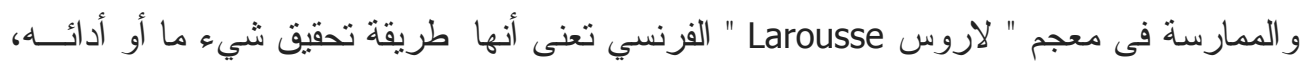

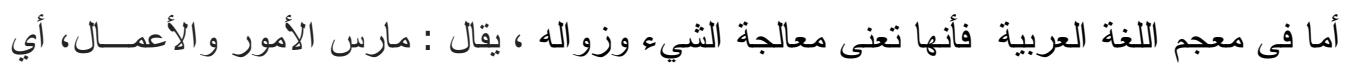

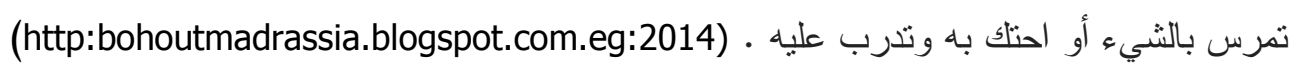
وتعتبر الممارسة Practice شرطا هاماً من شروط التعلم ، فالتعلم هو تغير شــبه دائــم فــي أداء

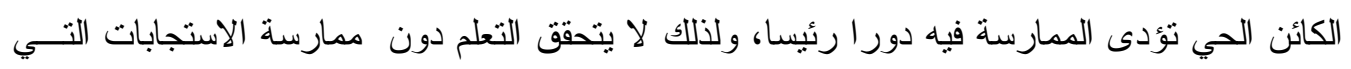
تحقق اكتساب المهارة المطلوبة سواء كانت مهارة حركية أو لفظية أو عقلية، وتساعد ممارسة الأداء

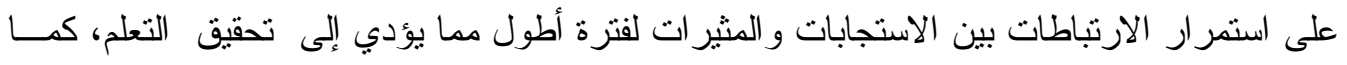

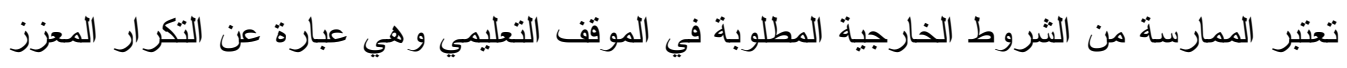

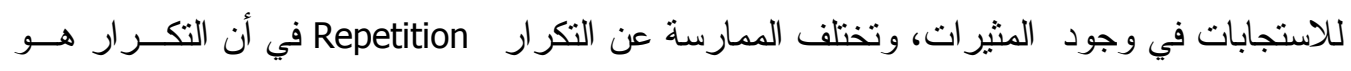

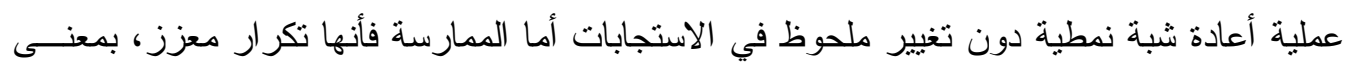

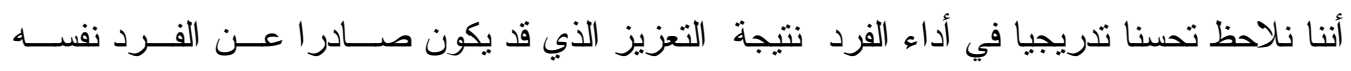

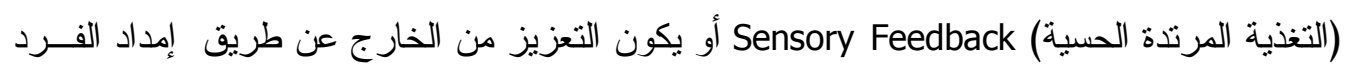

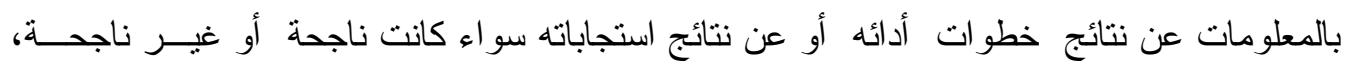

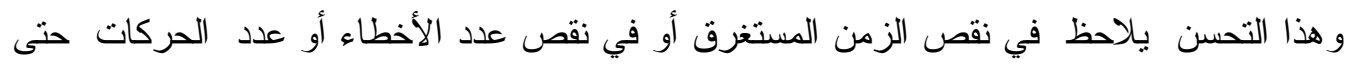

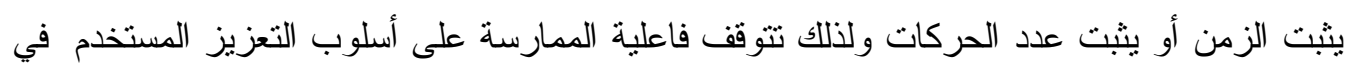

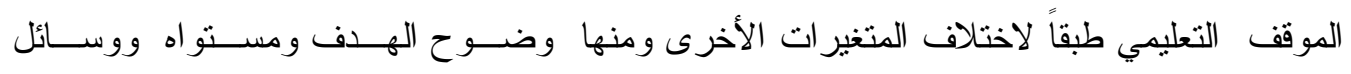
تحقيقه(faculty.ksu.edu.sa)

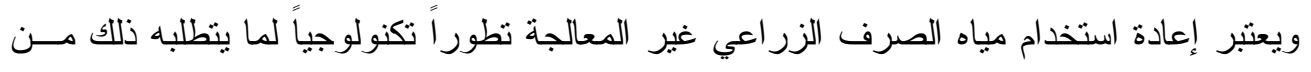

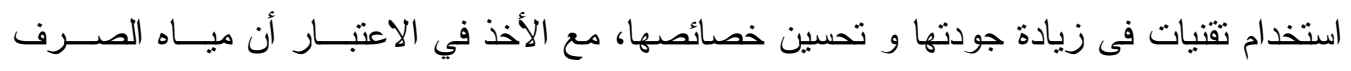

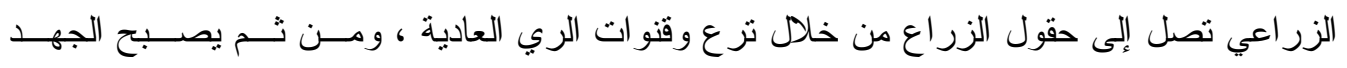

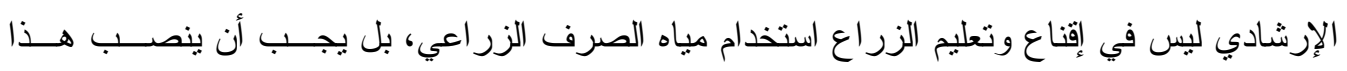

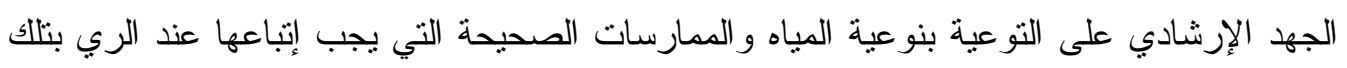
المياه، و أهمية اقتصار ها على المحاصيل غير الغذائية (القوصي، 243:1997).

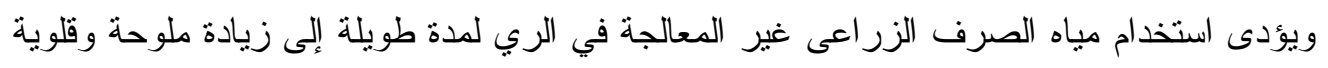

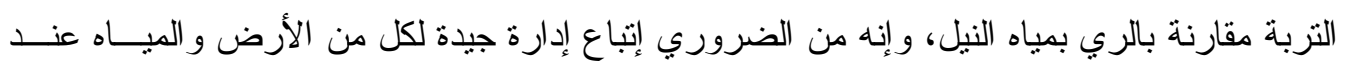




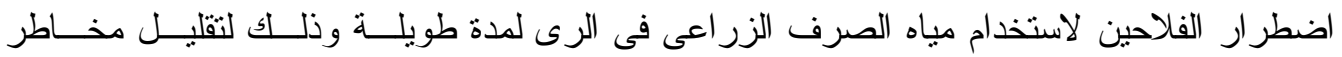

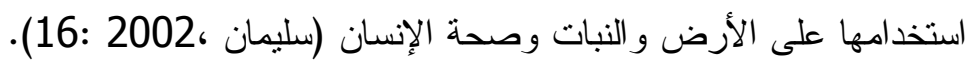

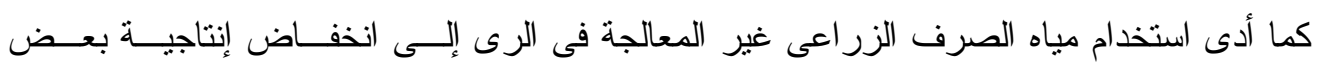

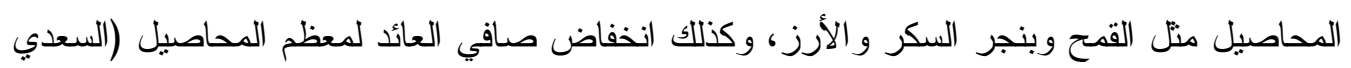

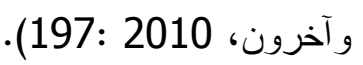
ولذا فمن الضروري عند استخدام مياه الصرف الزر اعي إعادة معالجتها في ظل الحدود المســموح

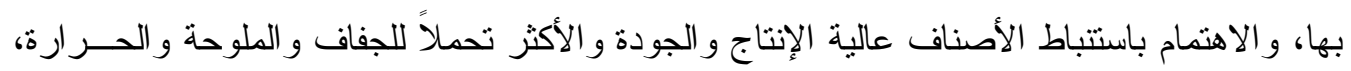

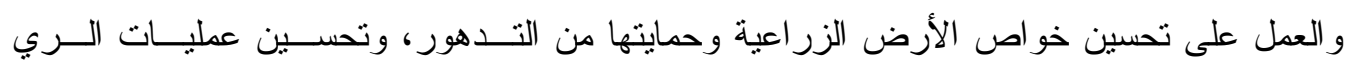

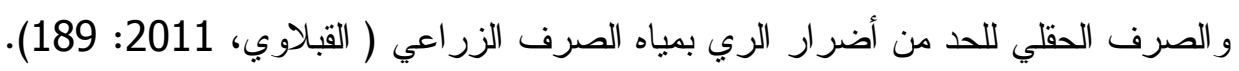

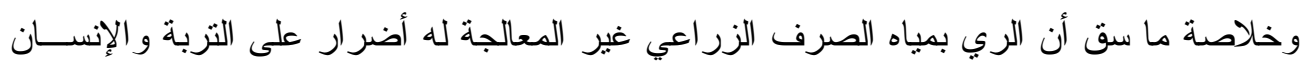

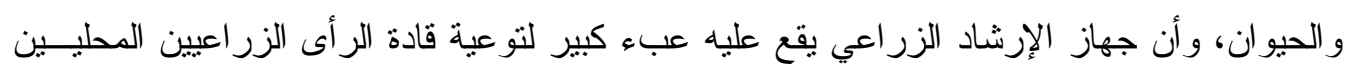

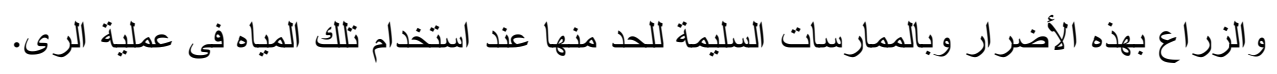

\section{الطريقـــة البحثبــة}

- منطقة البحث : تقع محافظة كفر الثيخ من الناحية الزر اعية في نهاية التزع و المصارف، حيث تتدر وتقل كميات

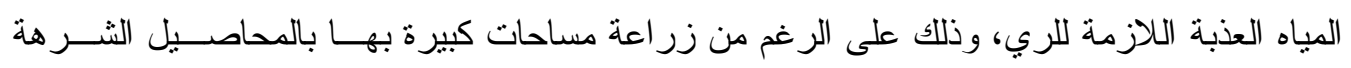

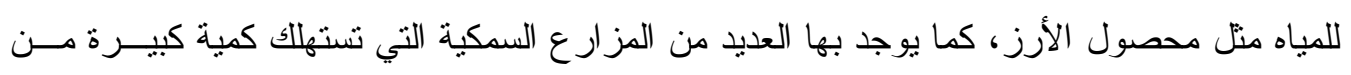

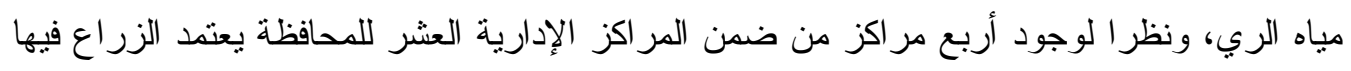

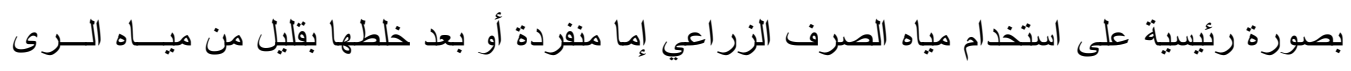

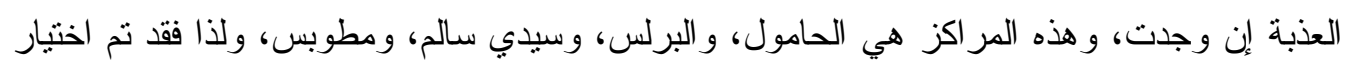
مركز من تلك المر اكز الأربعة بطريقة عشو ائية فوقع الاختيار على مركز سيدي سالم، كما تم اختيار

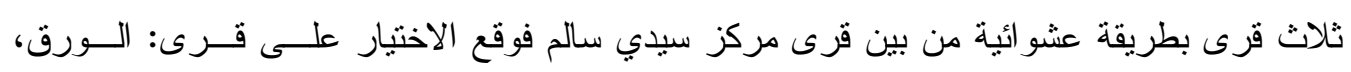
العمار ، سد خميس.

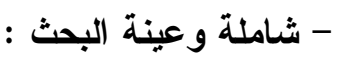

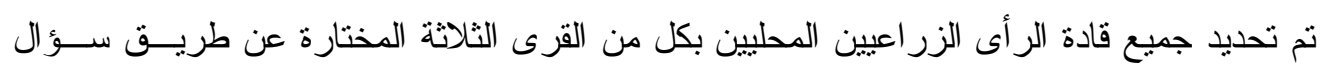

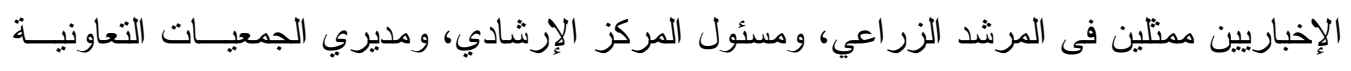

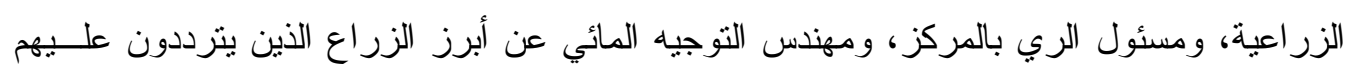

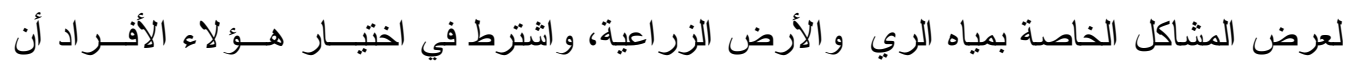

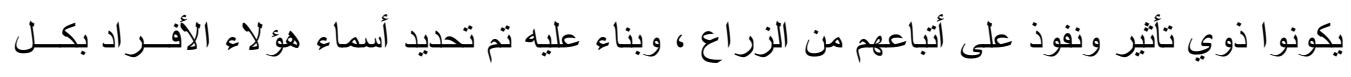

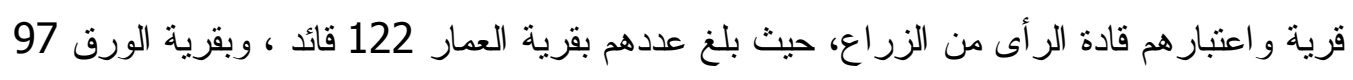

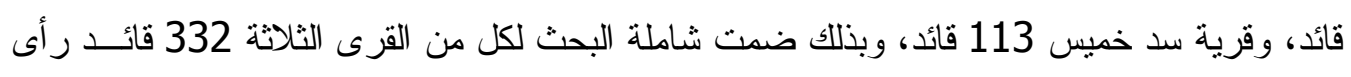
زر اعي، ونم تحديد حجم العينة طبقاً لجدول كريجسي ومورجان، ونم نوزيع هذا العدد على كل قرية 
من القرى الثلاث حسب نسبة تمثيل كل منها في شاملة الدراسة ،حيث بلغ إجمالي حجم العينــة 206 مبحوثا.

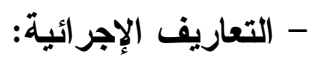

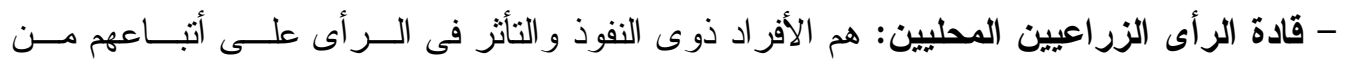

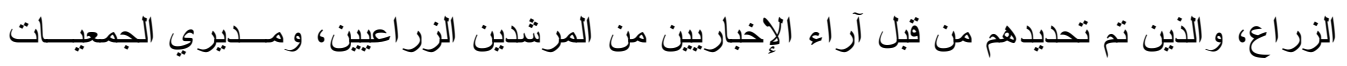

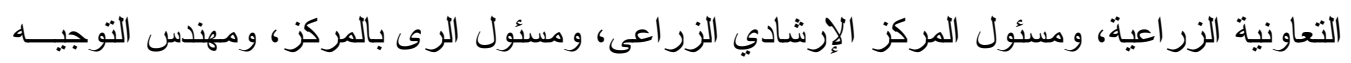
المائي. - معرفة قادة الرأى الزراعيين المحليين المبحوثين بأضرار الرى بمياه الصرف الزراعـي غيــر

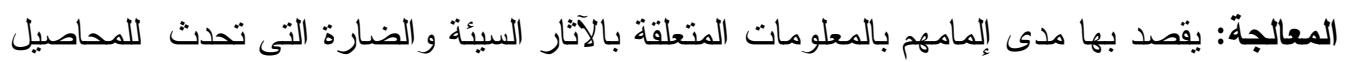

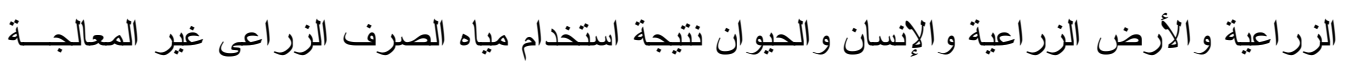

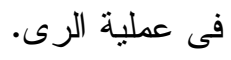
- معرفة قادة الرأى الزراعيين المحليين المبحوثين بالممارسات التي يجب إتباعها للحد من أضرار

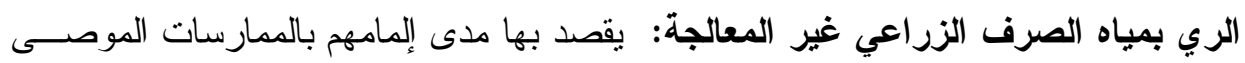
بها للدد من أضر ار الري بمياه الصرف الزراعير الزراعي غير المعالجة.

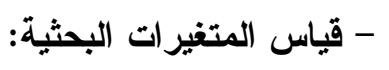
تم استذام الأرقام العددية فى قياس بعض المتنيرات للتمييز بين فئات كل متغير، حتى يســهل

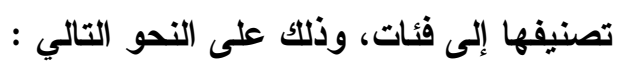

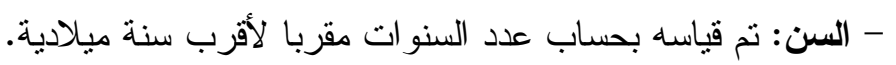

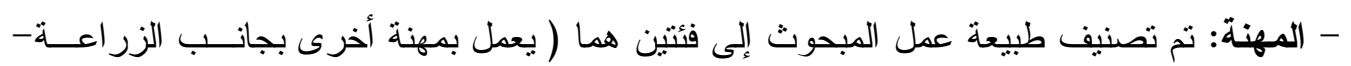

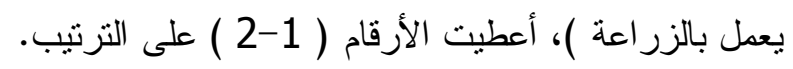

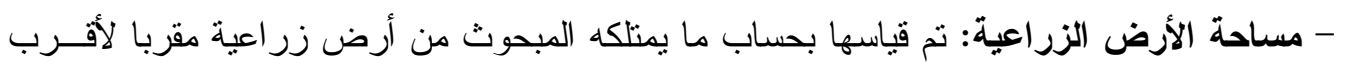

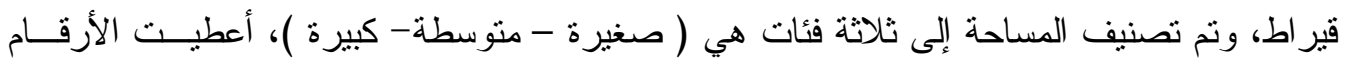

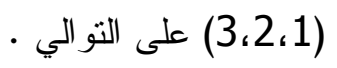

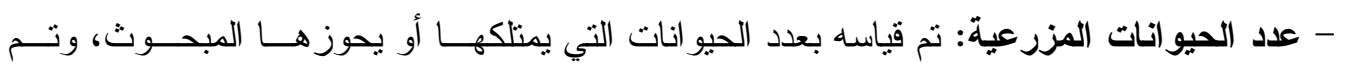

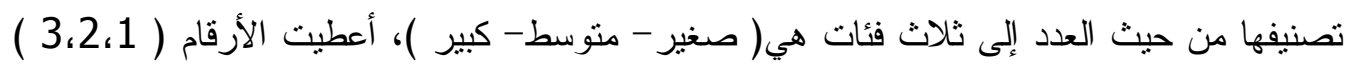
على الترتيب - الحالة التطليمية: تم قياسها بعدد السنوات التى قضاها المبحوث فى التعليم الحكومي الرسمي، وقد

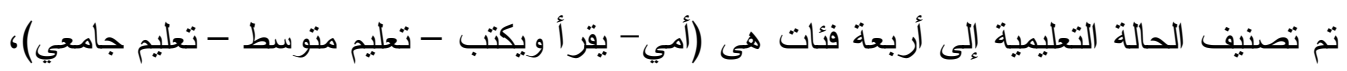

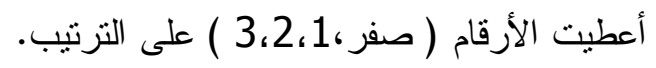

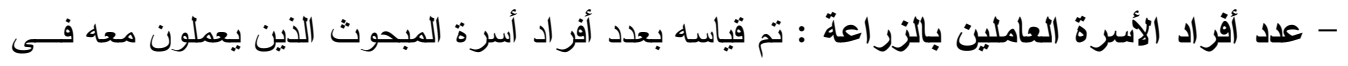
زر اعة الأرض، وتم تصنيفها إلى ثلاث فئات من حيث العدد إلى ( صغير - متوسط- كبير )، أعطيت

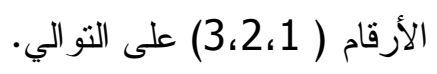


- عضوية المنظمات المحلية: نم تصنيف عضوية المبحوث فى المنظمات المحلية إلى أربعة فئسات

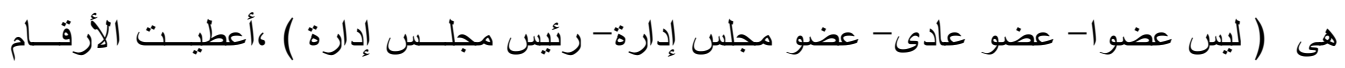

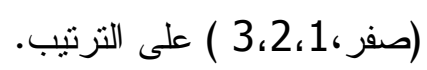

- مصادر المطلومات عن أضرار استخدام مياه الصرف الزراعى فئى في الرى وممارسات الحد من تلك

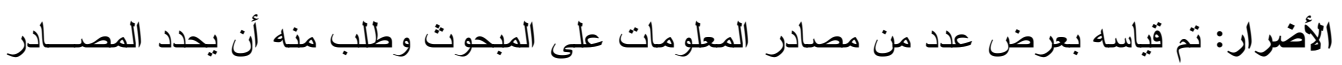

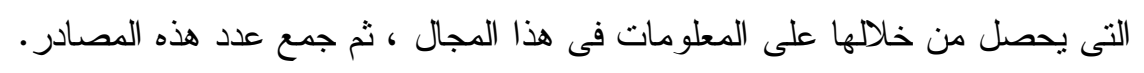

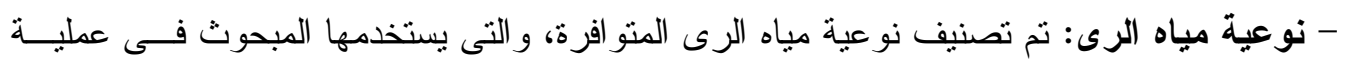

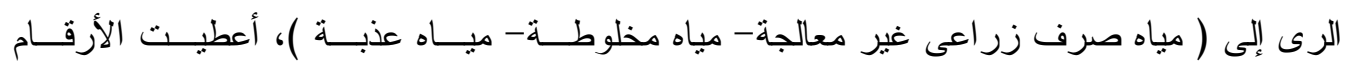

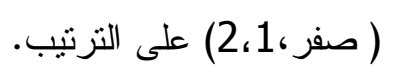

- الاعتماد على الرى بمياه الصرف الزراعى غير المعالجة: تم تصنيف المبحوثين من حيث مــدى

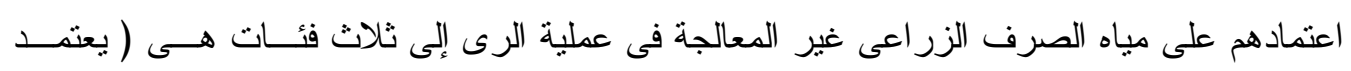

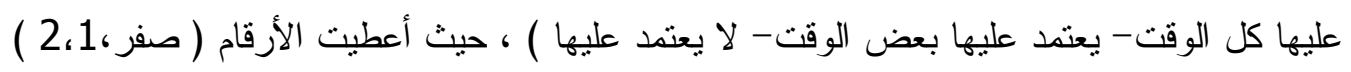
على التزنيب - موقع الأرض من مصدر الرى: تم تصنيف موقع الأرض وفقا لقربه من مصدر الرى إلى ثـلاث

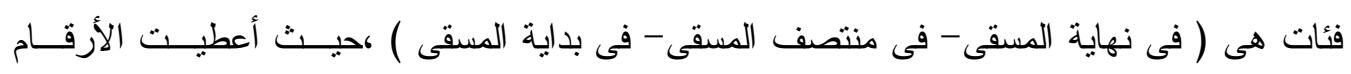

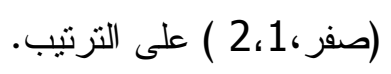

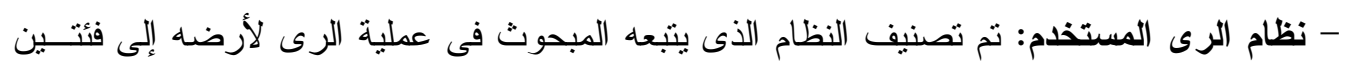
هما ( نظام رى غير مطور - نظام رى مطور)، حيث أعطى الأرقام (1، (1 ) على الترتيب.

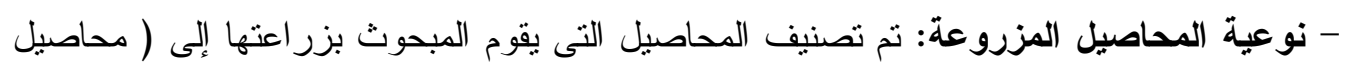
خضر ، محاصيل حقلية)، حيث أعطيت الأرقام (1،2) على الترتيب.

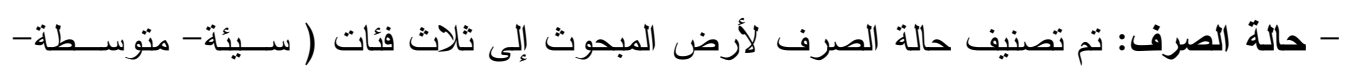

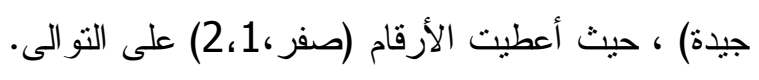

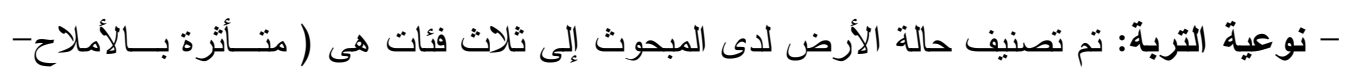

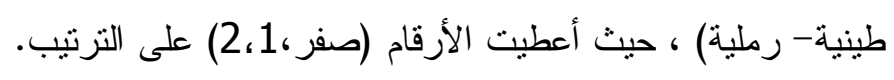

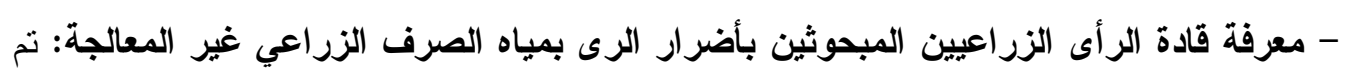

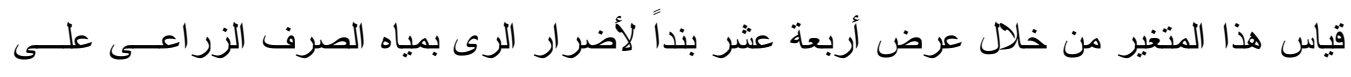

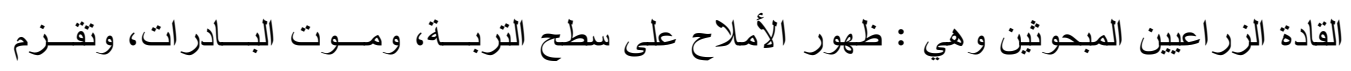

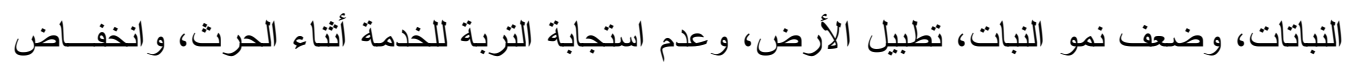

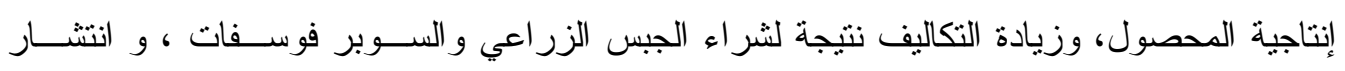

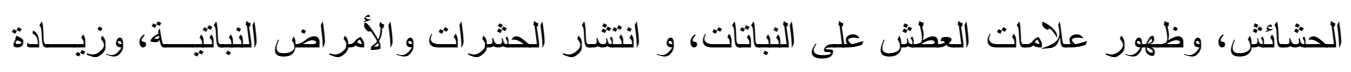

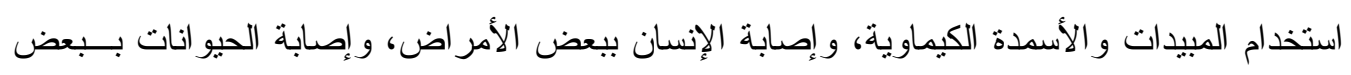

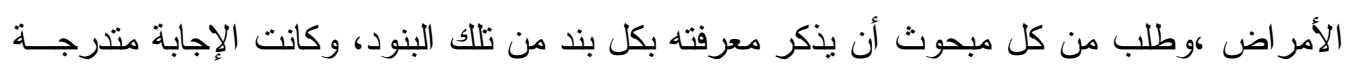

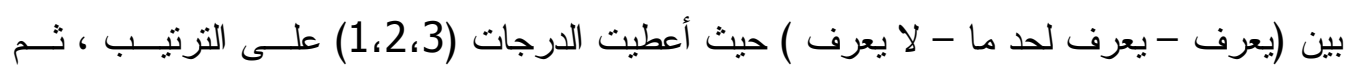




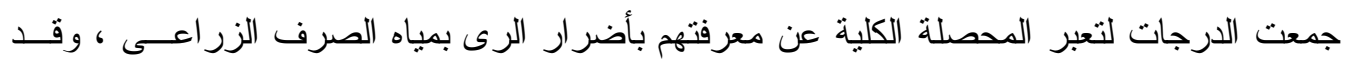
تز اوحت الدرجة النظرية لتلك المعرفة بين ( 14 - 42 ) درجة.

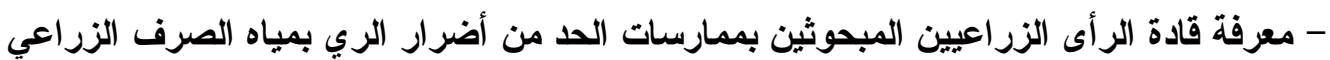

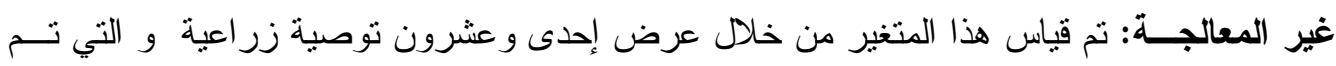

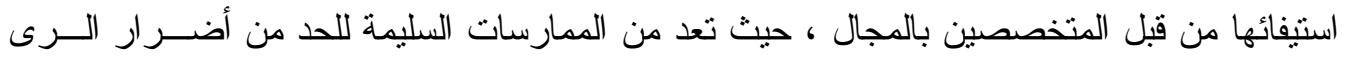
بمياه الصرف الزر اعى غير المعالجة على المبحوثين هى : التسوية الجيدة للأرض، و الصرف بلهن الجيد

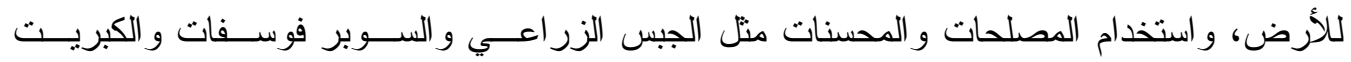

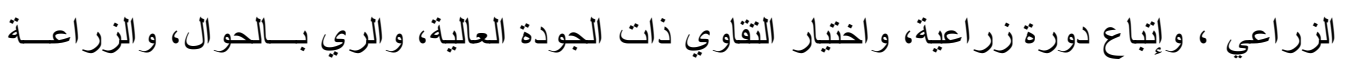

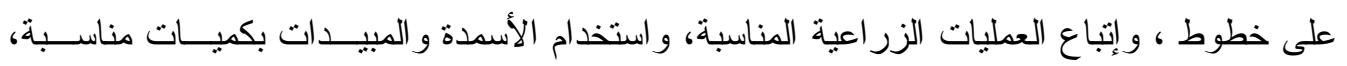

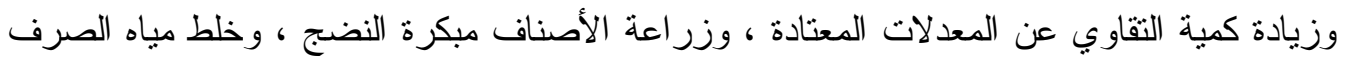

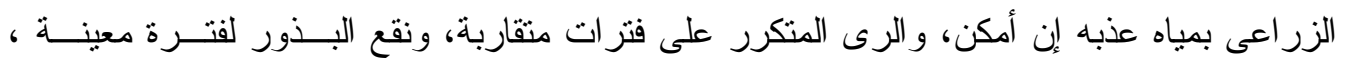

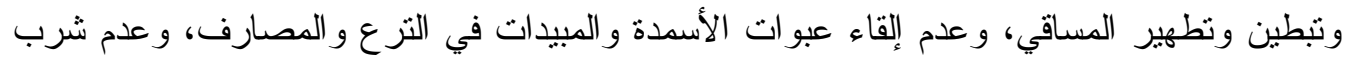

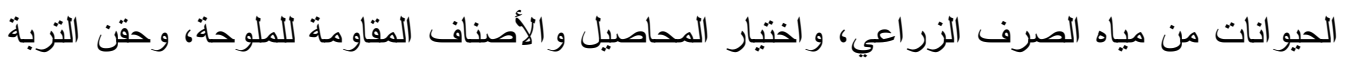
بالأمونيا، وعمل أنفاق لتحسين الصرف وتقليل الملوحة، ولبس قفاز ات للتعامل مع هذه المياه، وطلب ولب ولتبن

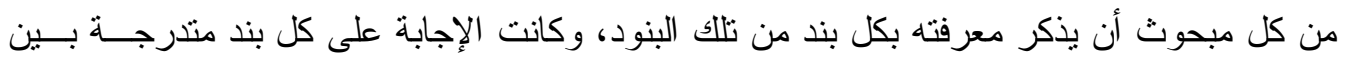

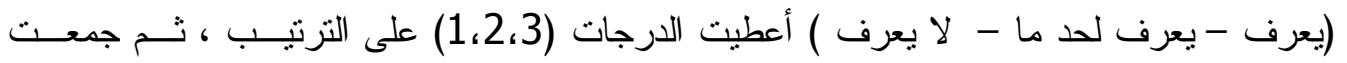

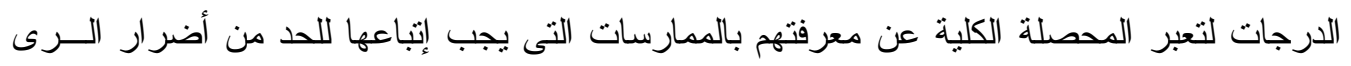
بمياه الصرف الزر اعى ، وقد نر اوحت الدرجة النظرية لتلك المعرفة بين ( 21 - 63 ) درجة.

\section{جمع وتحليل البيانات}

تم جمع البيانات البحثية خلال شهر مارس 2016م باستخدام استمارة الاستبيان بالمقابلة الثخصــية

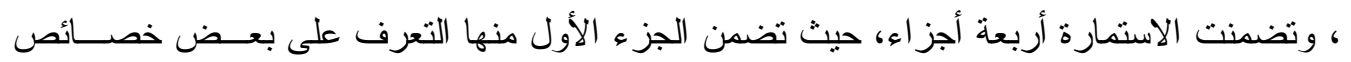

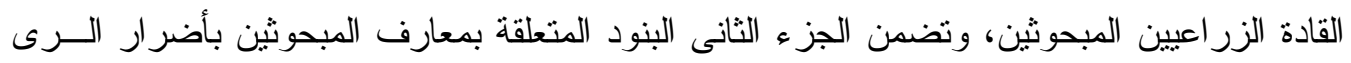

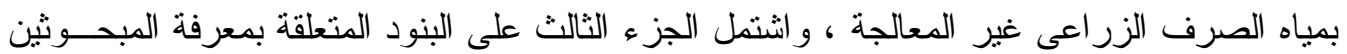

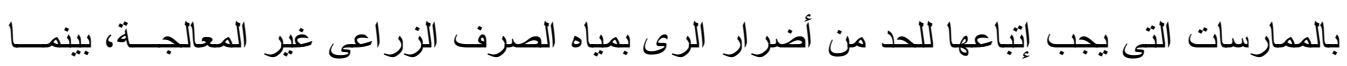

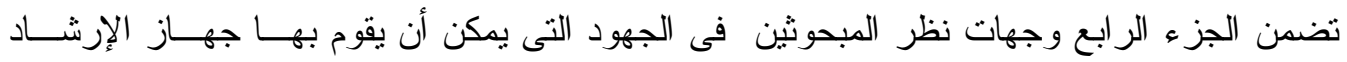

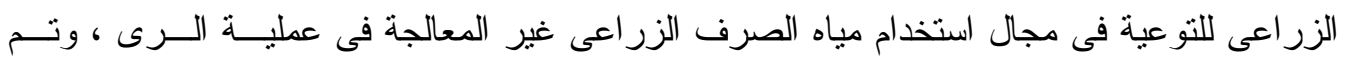

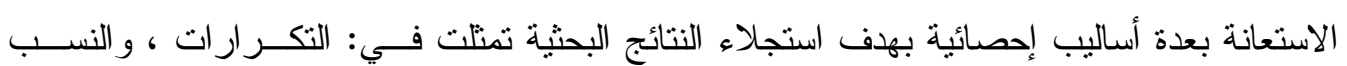

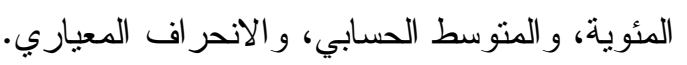

\section{النتائســ ومناقشتهـــا}

وصف بعض خصائص قادة الرأى الزراعيين المبحوثين: أوضحت النتائج البحثية بجـدول (1)

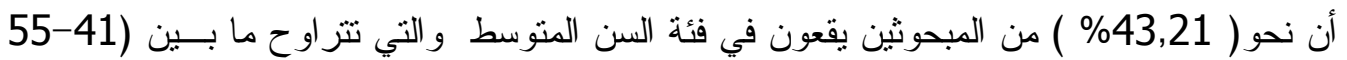

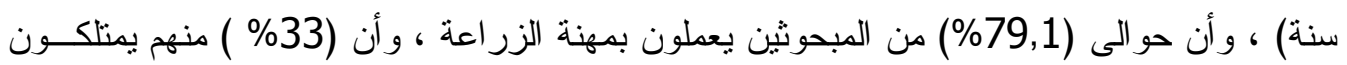
ما بين (6- 39) قير اط أرض زر اعية وهم يقعون في فئة الحياز ات الصغيرة ، و وأن نحو (37,4\%) 
من المبحوثين يمتلكون ما بين (120-81) قير اط وهم يقعون في فئة الحياز ات الكبيرة ، كما تبين أن قر ابة (73\%) من المبحوثين يمتلكون حيازة حيو انية ما بين (1- 2) حيو ان، وأن نحو (48,1\%) من فين

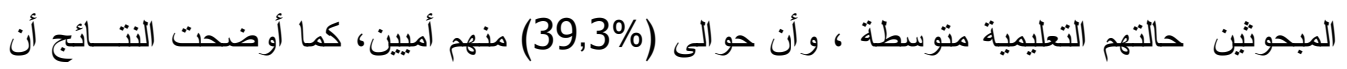

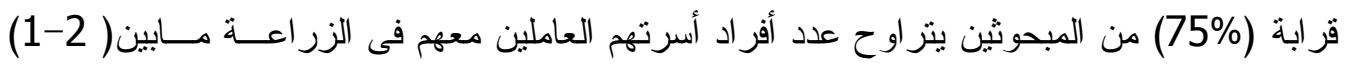

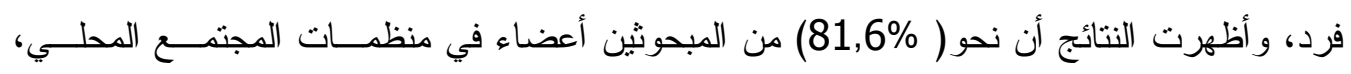

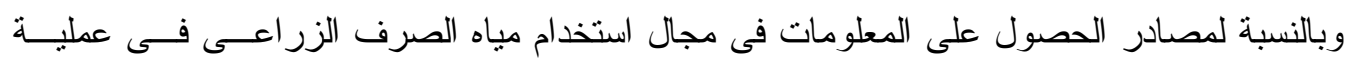

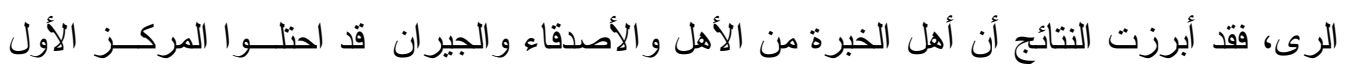
كمصدر لحصول القادة الزر اعيين المبحوثين على معلوماتهم فى هذا المجال وذللك بنسبة (22,3\%)،

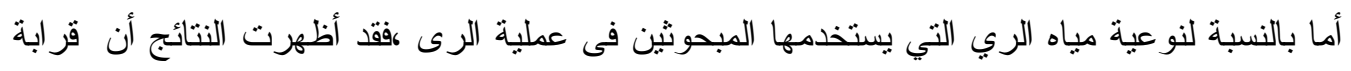

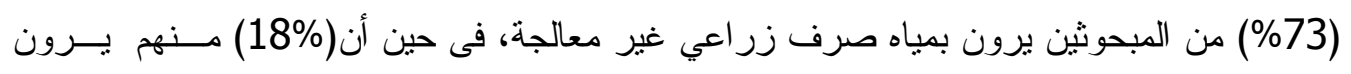

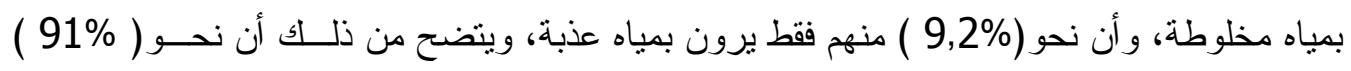
من إجمالي المبحوثين يرون بمياه صرف زر اعي غير معالجة ومياه مخلوطة ، أما بالنسبة للاعتمــاد

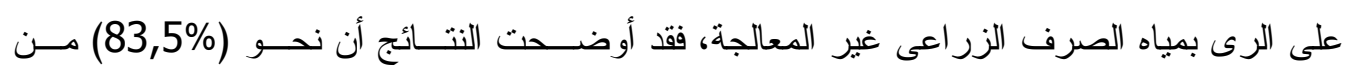

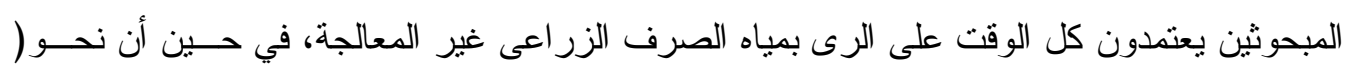

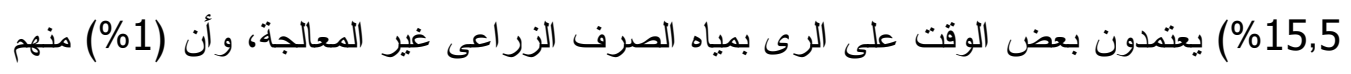

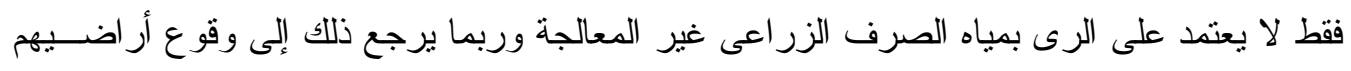

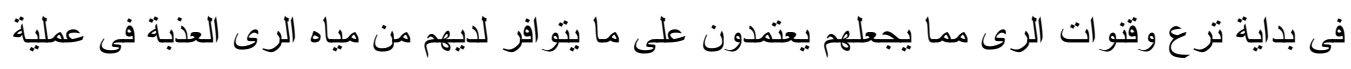

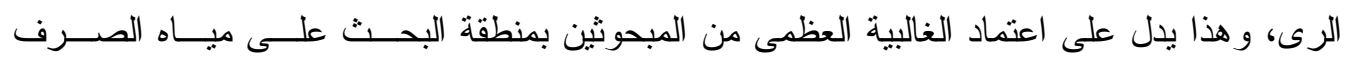

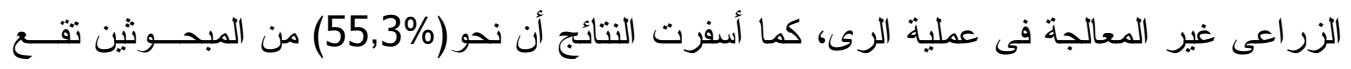
أر اضيهم فى منتصف المسقى،أن (30,6\%) منهم تقع أر اضيهم فى نهاية المسقى، كما كثفت النتائج

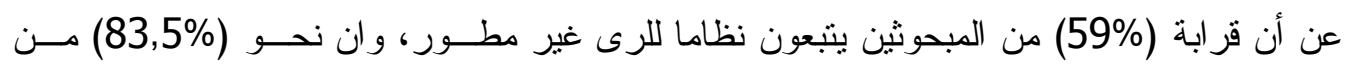

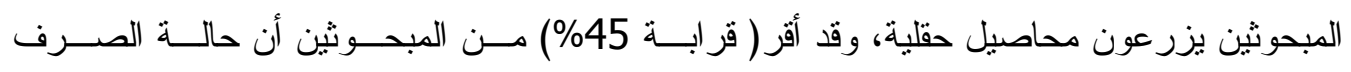

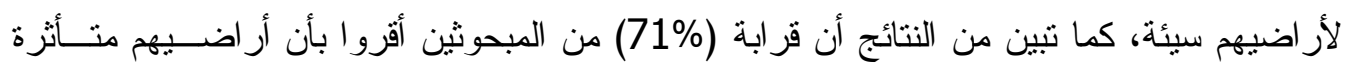
بالأملاح بدرجة كبيرة.

أولا : مستوى معرفة قادة الرأى الزراعيين المحليين المبحوثين بأضرار الــــى بميــاه الصــرف

$$
\text { الزراعى غير المعالجة. }
$$

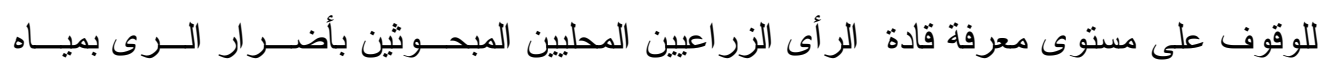

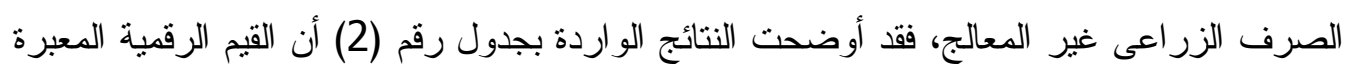
عن درجة معرفة المبحوثين بأضرار الرى بمياه الصرف الزر اعي غير المعالجة قد تر اوحت ما بين

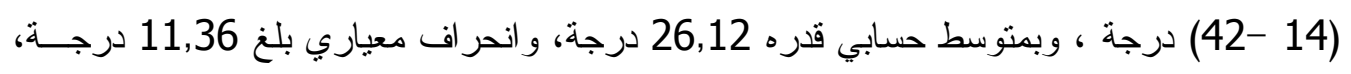

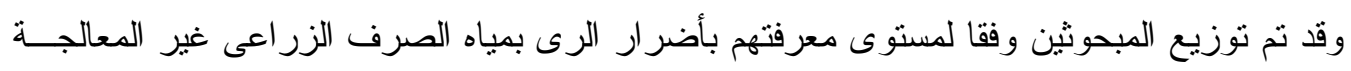

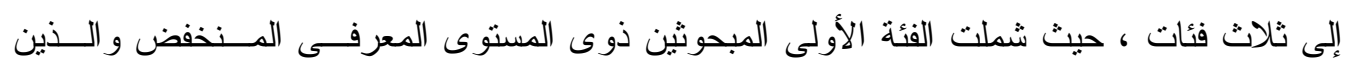

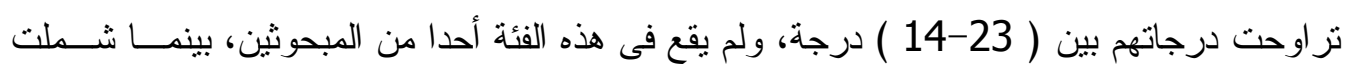


الفئة الثانية المبحوثين ذوى المستوى المعرفى المتوسط والنى تراوحت بين (33-24 ) درجة ،حيث بلغت نسبتهم بتلك الفئة 21,4\% من إجمالي المبحوثين، فى حين تضمنت الفئة الثالثة على المبحوثين

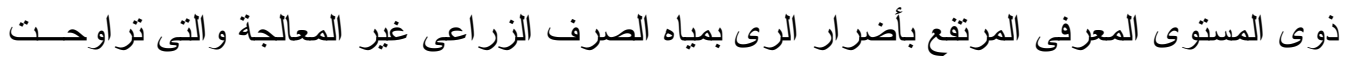

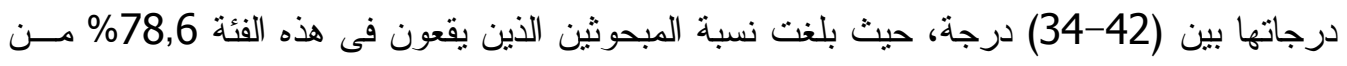

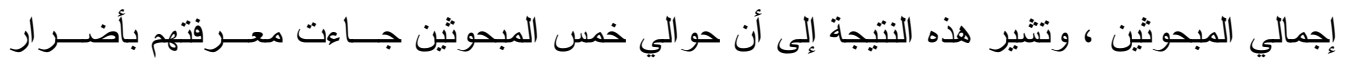

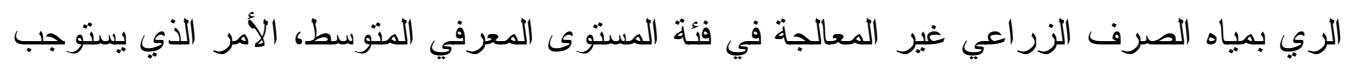
زيادة معارفهم بنلك الأضر ار.

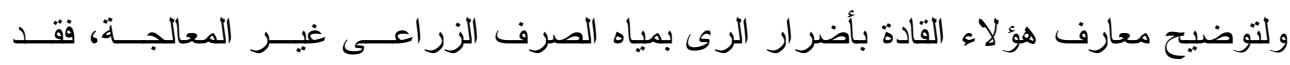

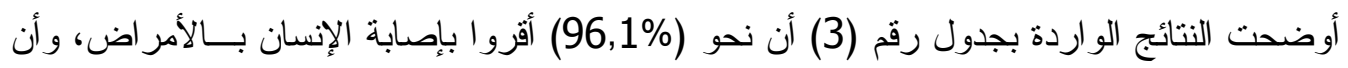

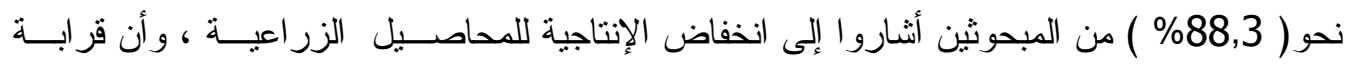
(86\%) منهم أقروا بظهور أملاح على سطح التربة ، و أثنار قر ابة (76\%) منهم إلى زيادة انتشــار

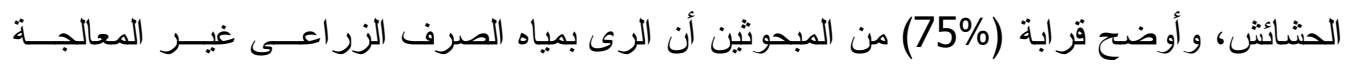

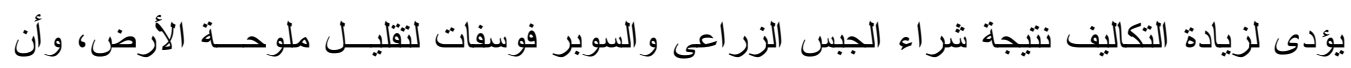

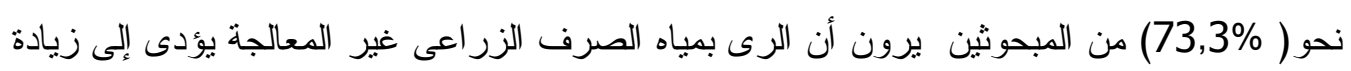

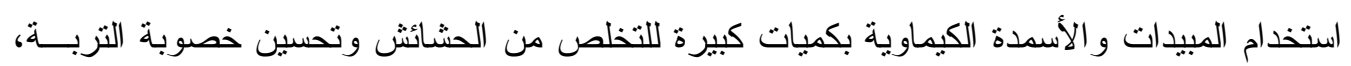

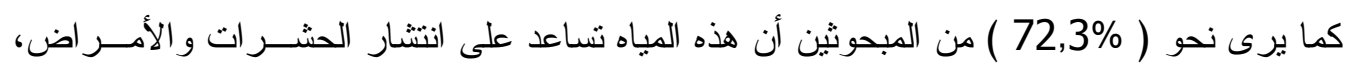

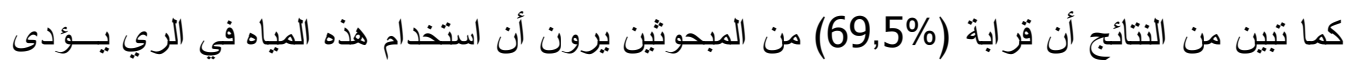

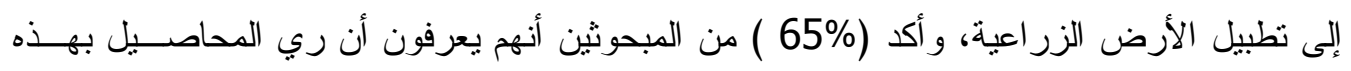

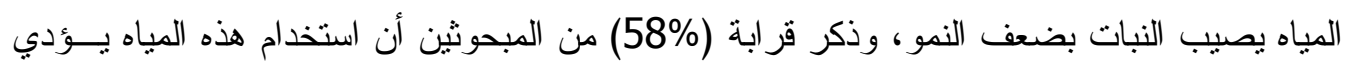

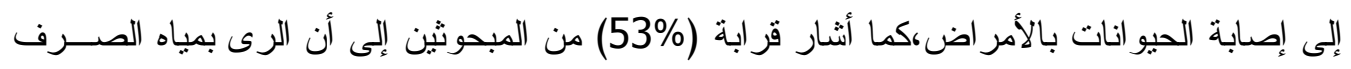

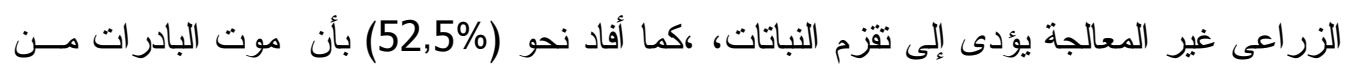

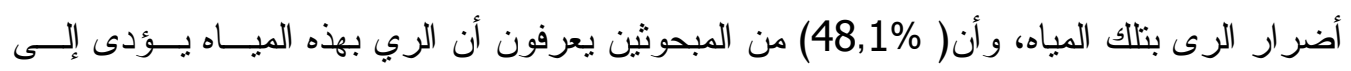
ظهور علامات العطش على النباتات ، و أخير ا أوضح قر ابة (24\%) من القادة الزر اعيين المبحوثين أن الرى بمياه الصرف الزر اعى غير المعالجة يؤدى إلى عدم استجابة التزبة للخدمة أثثاء الحرث.

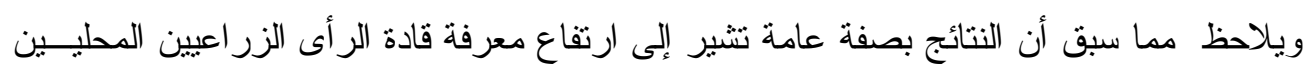

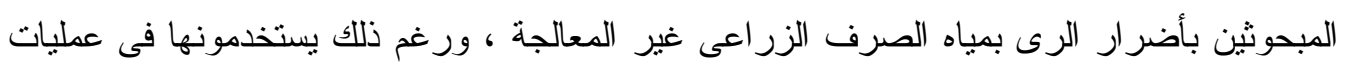

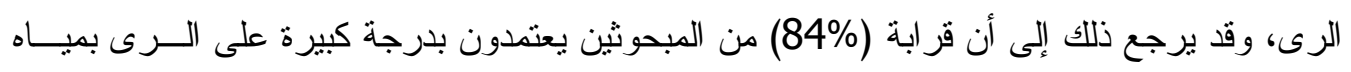

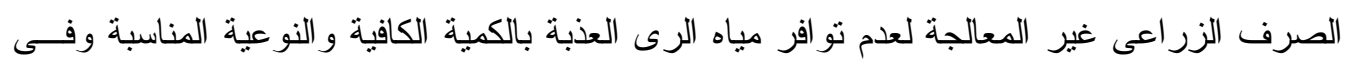
التوقيت المناسب لاحتياجات المحاصيل من المياه العذبة . 
ثانيا: مستوى معرفة قادة الر أى الزراعيين المحليين المبحوثين بممارسات الحد من أضرار الــري بمياه الصرف الزراعي غير المعالجة.

أظهرت النتائج الواردة بجدول (4) أن القيم الرقمية المعبرة عن درجة معرفة قادة الر أى الزر اعيين

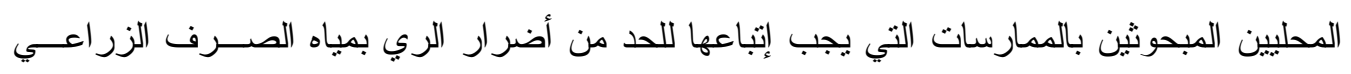

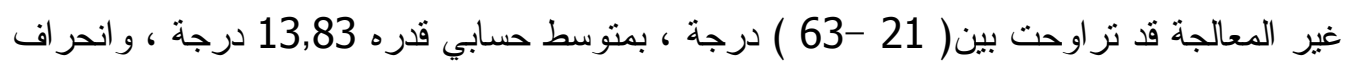

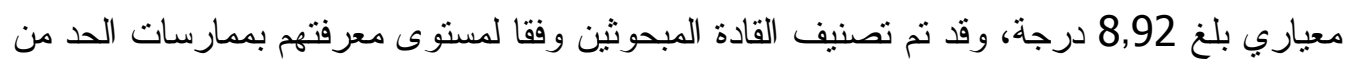

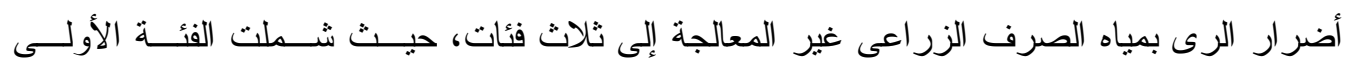
المبحوثثن ذوى المستوى المعرفى المنخفض بنلك الممارسات و الذين نز اوحت درجاتهم بــين ( 21-

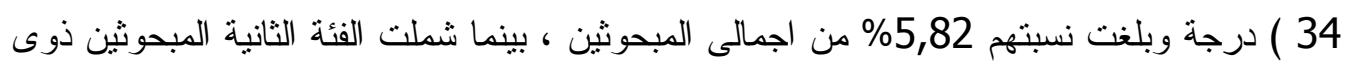

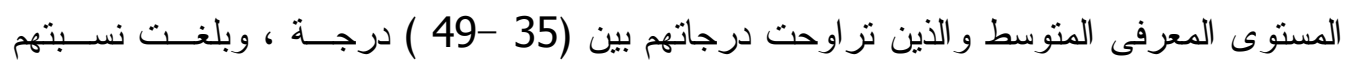

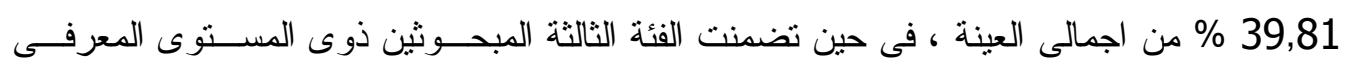

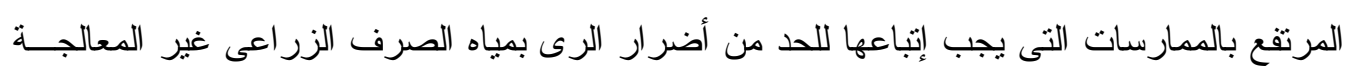

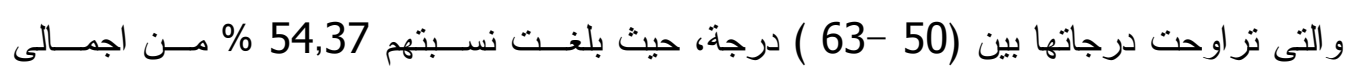

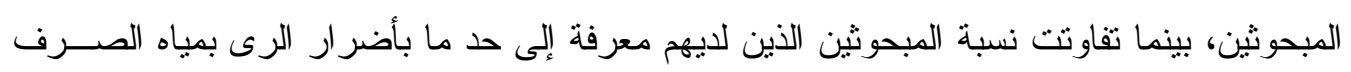

$$
\text { الزراعى غبر المعالجة. }
$$

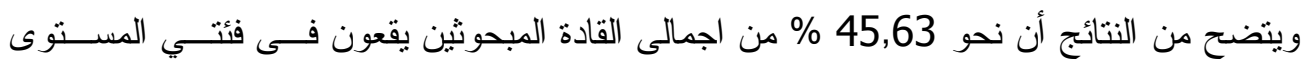

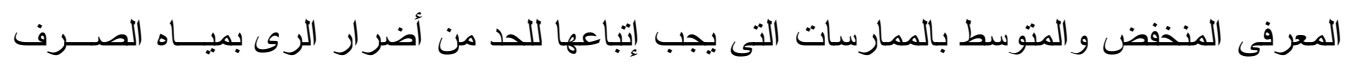

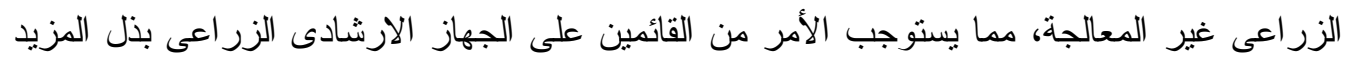

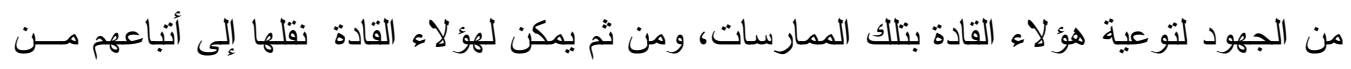

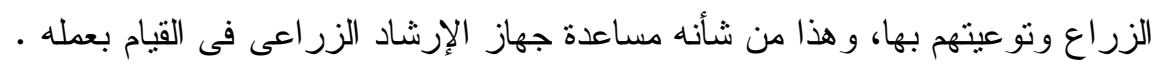

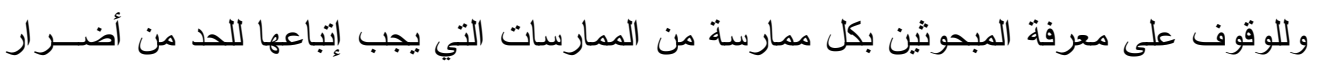

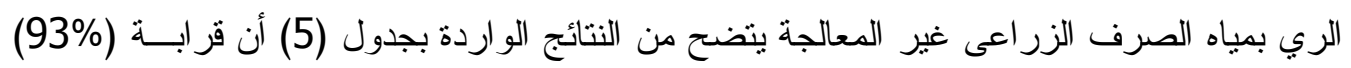

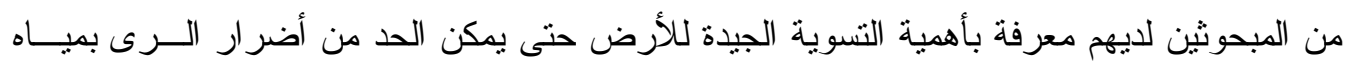

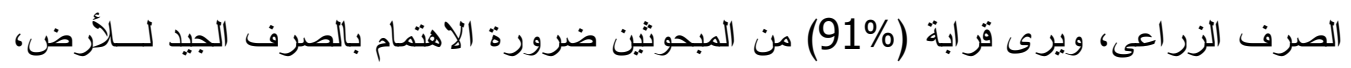

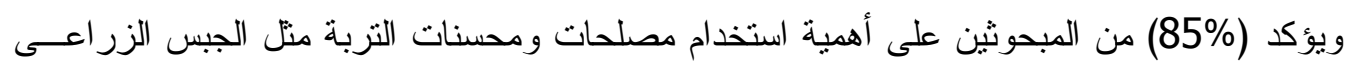

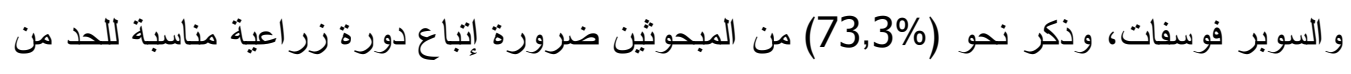

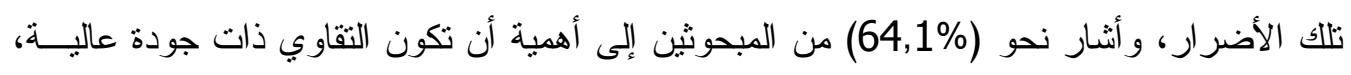

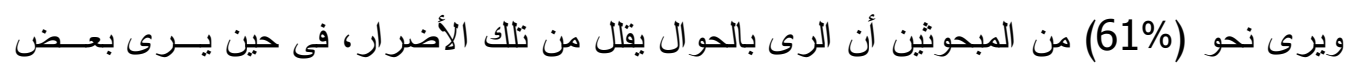

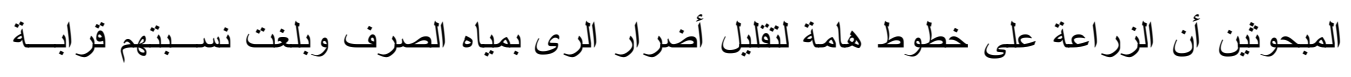

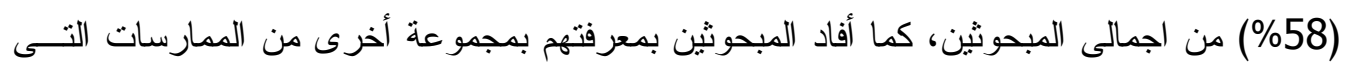

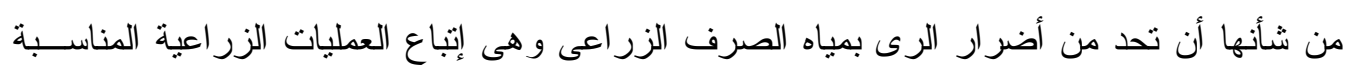

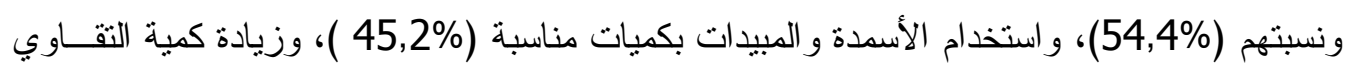

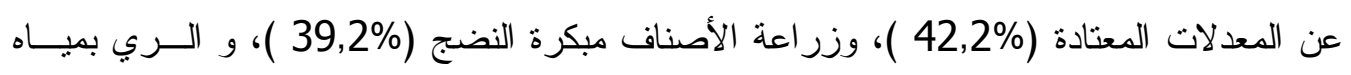




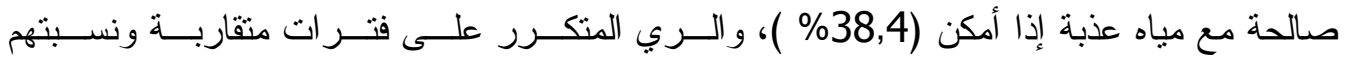

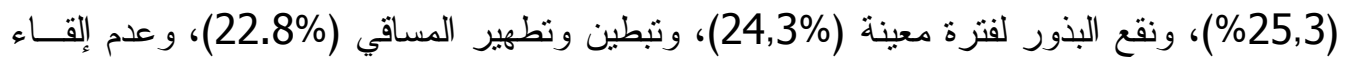

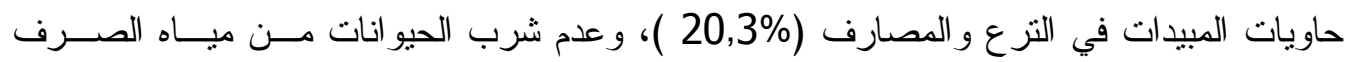

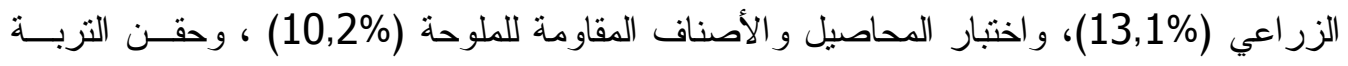

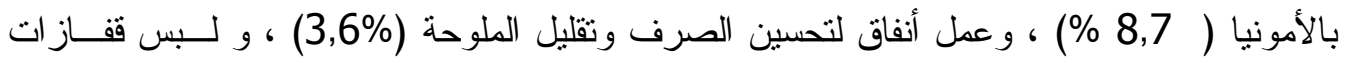

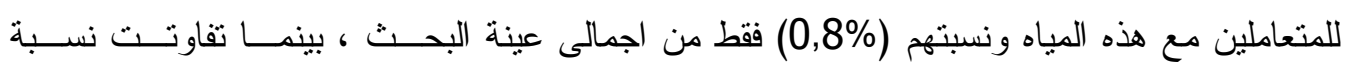

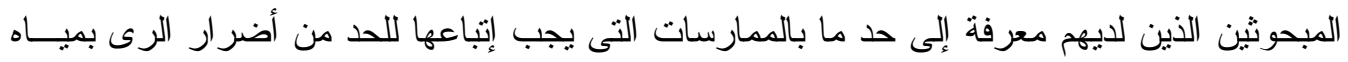

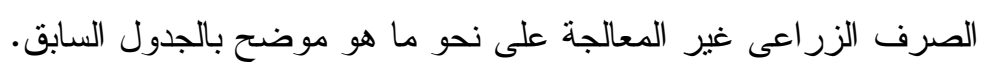

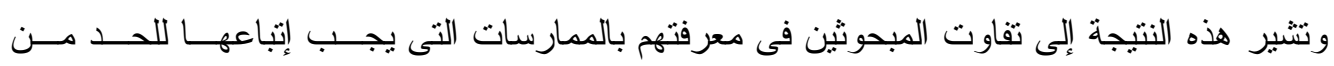

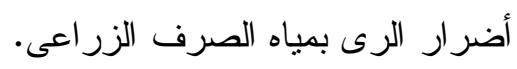

ثالثا: وجهات نظر قادة الرأى الزراعيين المحليين المبحوثين فيما يجب أن يقــوم بهـــا الإرشـــاد

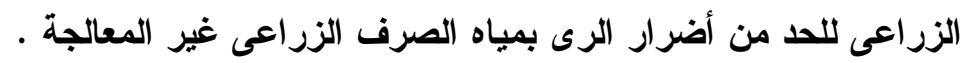

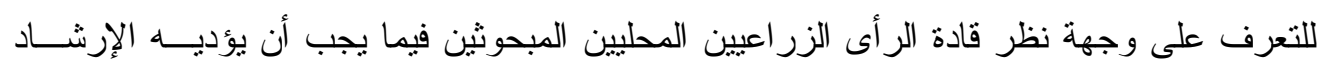

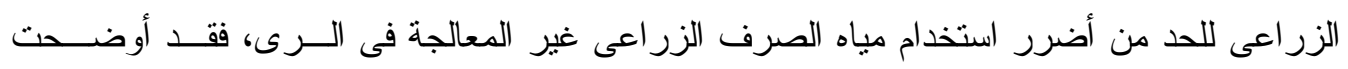

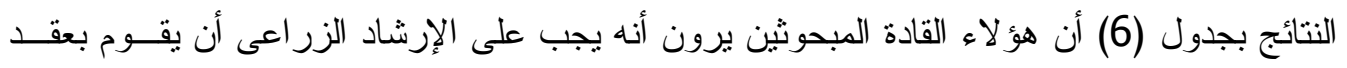
دور ات تدرييية للتوعية بأضر ار الرى بتلك المياه حيث أقر بذلك (

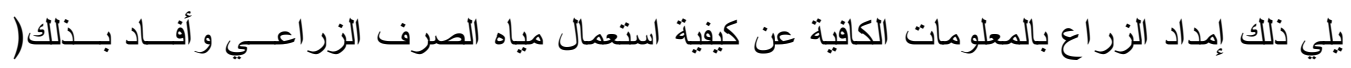

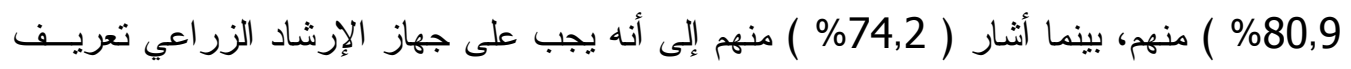
الزراع بالمقننات المائية للفدان من مياه الصرف الزراعي، ويرى (

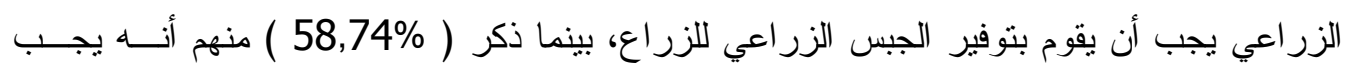

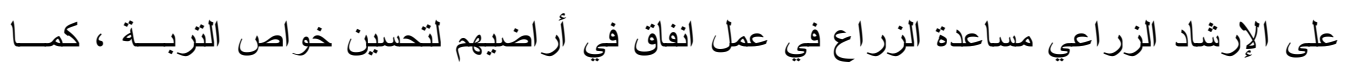

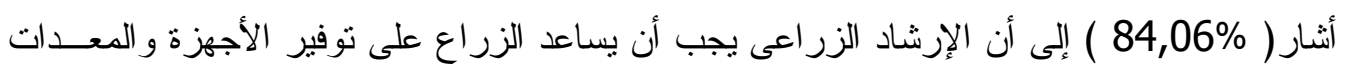

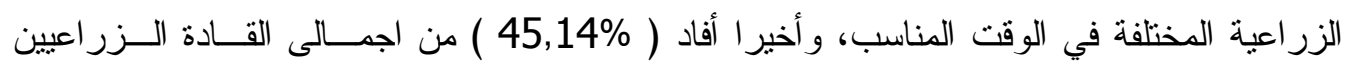

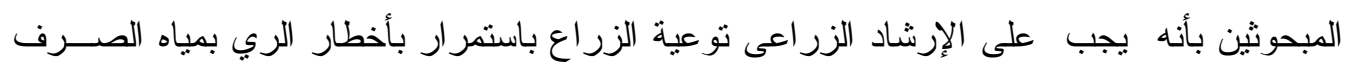
الزر اعي غير المعالجة.

\section{توصيات البحث}

1- إمكانية إعادة استخدام مياه الصرف مباشرة بعد معالجتها أو بعد خلطها بالمياه العذبة بنســب

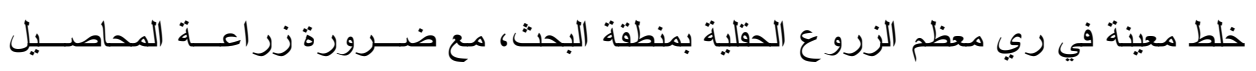

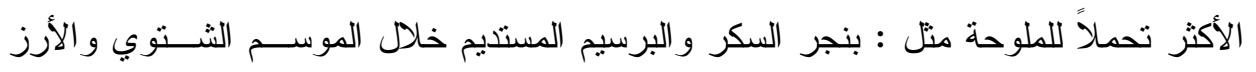
و القطن خلال الموسم الصيفي و غير ها. 2- أن يكون هنالك توعية بالمناطق التي تنتخدم مياه الصرف الزر اعى و المتعاملين معها وكـــللك

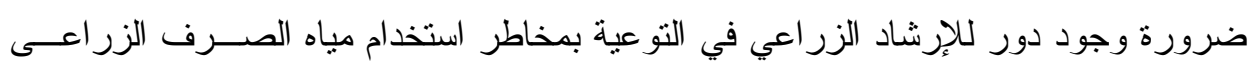
غير المعالجة تلك المياه وكيفية تجنب تلك المخاطر . 


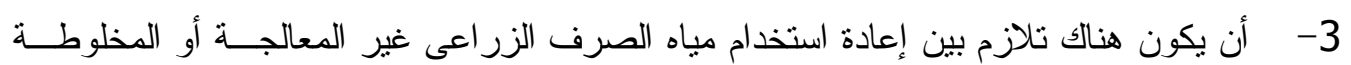

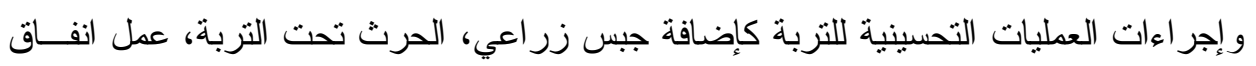

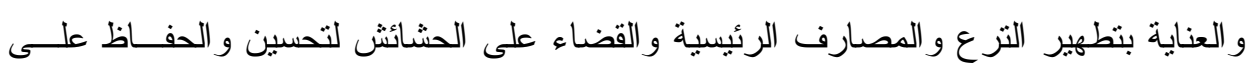
المستوى الحالي لخصوبة التزبة و عدم تدهور ها مستقبلاً.

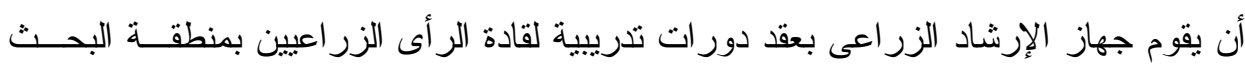

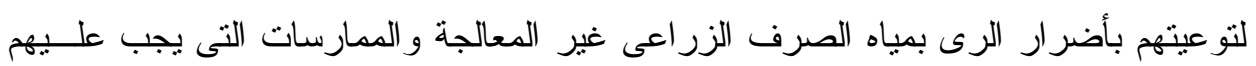
إتباعها للحد من أضرار الرى بنانلك المياه.

\section{المر اجـع}

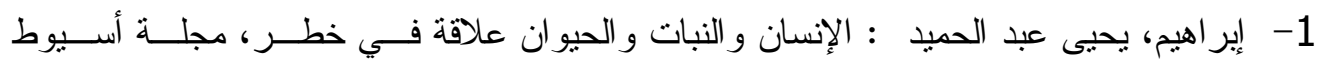

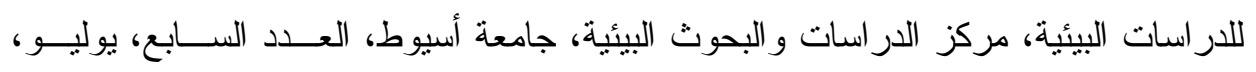
.1994

2- أبو السعود، خيري حسن : التتظيم و التخطيط و التقييم، مديرية التربية و التعليم، الجمهوريــة

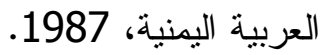

3- أبوزيد، رضا حسن عبد الغفار : ترشيد استخدام مباه الري بين القادة والأتباع مــن الــزراع

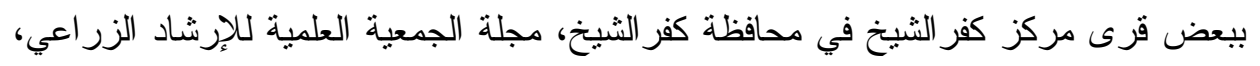
جامعة القاهرة، العدد 2، 2015.

4- إسماعيل، عمرو: ثقافة المياه تتنقل من الوفرة إلى الندرة، جريدة التعاون، مارس، 2013.

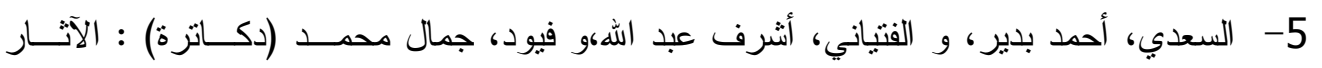

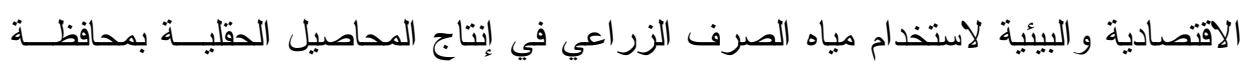
كفر الثيخ، المجلة المصرية للاقتصاد الزر اعي، المجلد العشرون، مارس، ولئه 2010. 6- القبلاوي، مصطفى عبد ربه محمد اقتصاديات استخدام نوعيات مختلفة من المياه الإرو ائية

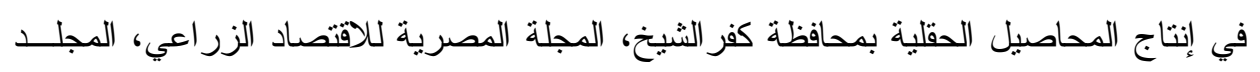

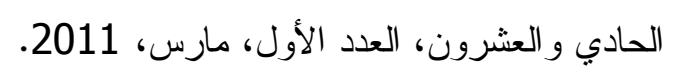

7- القوصي، ضياء الدين : الموارد المائية التقليدية وغير التقليدية في جمهورية مصر العربيــة

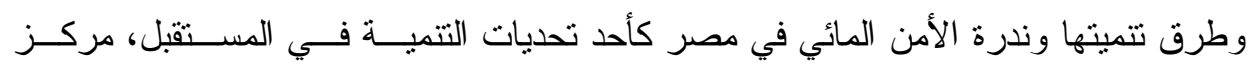

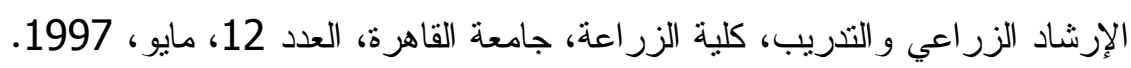

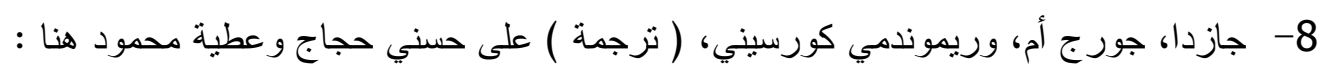

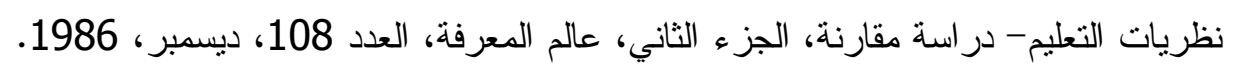

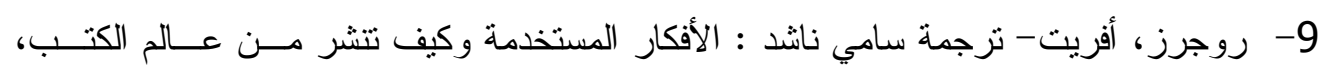
القاهرة، بدون ناريخ.

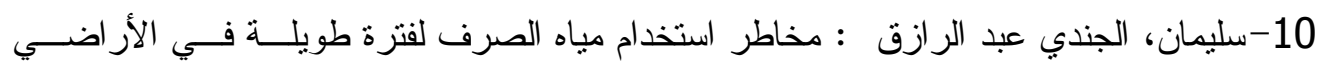

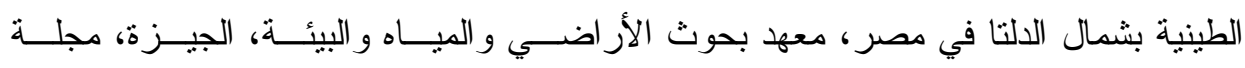

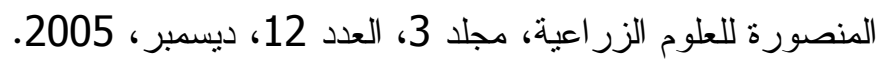


11-شرشر ، حسن على : آلية نشر الوعي البيئي ووسائل التكيف مع تغير المناخ وندرة الميــاه،

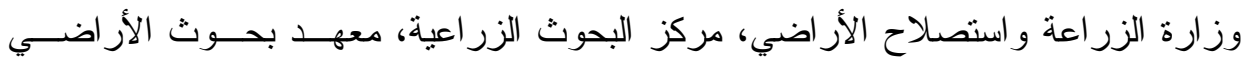

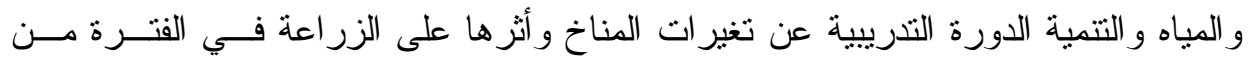

.2007/11/15-2007/1/4

12-عامر، محمد حسن: استخدام مياه الصرف في الري، مؤتمر البحث العلمي في مجــال الــري

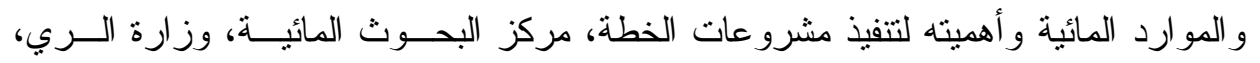

$$
\text { أكتوبر ، } 1984 .
$$

13-عبد العزيز ، يحيى : الخطة القومية لتطوير الري بالأراضي القديمة بالوادي و الدلتا، المجلـــة

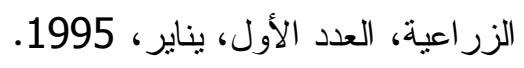

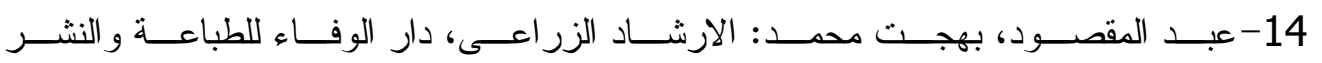

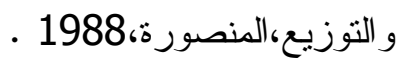

15-عطية، بيومي : المحاور المرتبطة لتتمية الموارد المائية وتطوير استخدامها في مصر، ، ندوة الأمن المائي في مصر كأحد تحديات التتمية في المستقبل، كلية الزر اعة، جامعـــة القــاهرة،

$$
\text { مايو، } 1997 .
$$

16- - عمر، أحمد محمد، وآخرون : المرجع في الإرشــاد الزر اعـي، دار النهضـــة العربيــة،

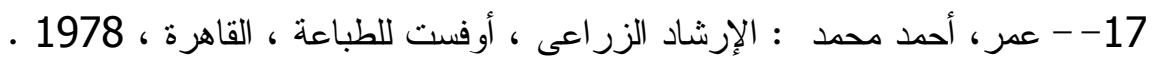

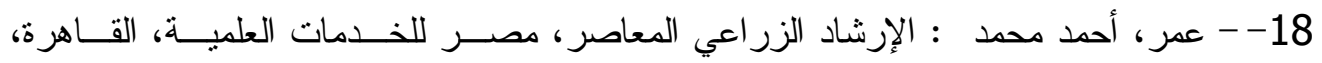

19- - قنطه،عبد الحليم عباس: نحو رؤية لتطوير الخدمة الإرشادية الزر اعية فى مصر ، مؤتمر"

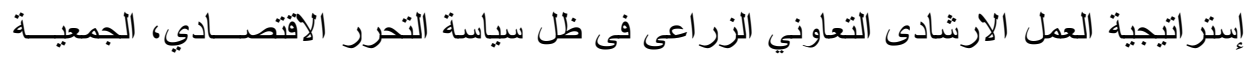
العلمية للإزشاد الزر اعى،القاهرة، 27-28 نوفمبر ،

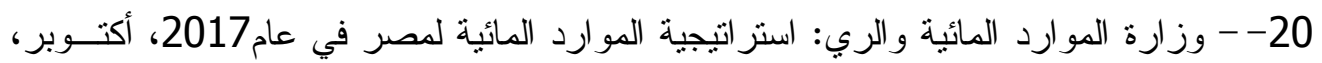
.1997

21-- وزارة الموارد المائية و الري : المركز القومي للبحوث المائية- معهد بحــوث الصــرف،

$$
\text { بيانات غير منشورة، } 2006 .
$$

22- Abd El-Naim E,M: Ibrahim A.E. and Eshal M.E. (1982) : A Preliminary Study The Effect of Using Sewage Water in Sandy Solls, Res. Bull. Ain Shams Univ., 1965, 112.

23- Allam, M.A. and Allam. G.A. Water Resources in Egypt: Future Challenges and opportunities, IWRA, Water International V. (39), N. (2), 2007.

24- Rogers E.M. and Shoemaker, FF Communication of Innovation Across Cultural Approach, an Edition the free P New York, USA, 1971.

25- http:bohoutmadrassia.blogspot.com.eg:2014.

26- Faculty.ksu.edu.sa/74119/DocLi, visited in 24 August,2016. 


\section{الجداول}

جدول رقم (1) : توزيع قادة الرأى الزر اعيين المحليين المبحوثين وفقًا لخصائصهم المدروسة

\begin{tabular}{|c|c|c|c|c|c|}
\hline$\%$ & عدد & المتغيـــــــر & $\%$ & عدد & المتغيـــــــر \\
\hline & & (7) عضوية المنظمات المحلية : & & & (1) السن : \\
\hline 81.8 & 168 & - عضو عادي & 15.53 & 32 & - صغير (40-27) سنة \\
\hline 18 & 37 & - عضو مجلس إدارة & 43.21 & 89 & - متوسط (55-41) سنة \\
\hline \multirow[t]{2}{*}{4} & 1 & - رئيس مجلس إدارة & 41.26 & 85 & - كبير (69-56) سنة \\
\hline & & 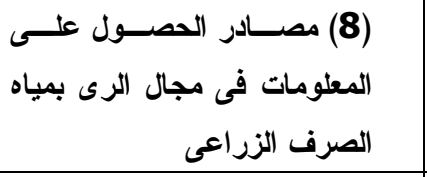 & & & (2) المهنـــــــة : \\
\hline 22,3 & 46 & 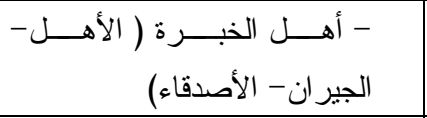 & 79.1 & 163 & - يعمل بالزر اعة \\
\hline 18.9 & 39 & - الإرشاد الزر اعى & 20.9 & 43 & الزر اعة - يعمل بمهنة أخرى بجانــب \\
\hline 11.2 & 23 & - الخبرة الثخصية & & & (3) مساحة الأرض الزراعية : \\
\hline 9,7 & 20 & - التليفون المحمول & 33 & 68 & - صغيرة (39-6) قبر اط \\
\hline 8.3 & 17 & - شبكة المعلومات & 29.6 & 61 & - متوسطة (80-40) قير اط \\
\hline 6,8 & 14 & - محلات المبيدات & 37.4 & 77 & - كبيرة (120-81) قير اط \\
\hline 5,8 & 12 & - وسائل الإعلام & & & (4) عدد الحيوانات المزرعية: \\
\hline 5.3 & 11 & - المياه - أعضاء روابـــ مســتخدمى & 72.8 & 150 & - صغير (2-1) حيوان \\
\hline 4.9 & 10 & - مركز البحوث الزر اعية & 19.4 & 24 & - متوسط (4-3) حيو ان \\
\hline 3.9 & 8 & - الزيار ات الحقلية و المنزلية & 7.78 & 16 & - كبير (6-5) حيوان \\
\hline \multirow[t]{2}{*}{2.9} & 6 & - مهندس التوجيه المائى & & & (5) الحالة التعليمية : \\
\hline & & (9) نوعية مياه الري : & 39.3 & 81 & - أمـــــي \\
\hline 72.8 & 150 & معالجة بـياه صرف زر اعي غير & 3.4 & 7 & - يقر أويكتب \\
\hline 18 & 37 & - ري بمياه مخلوطة & 48.1 & 99 & - تعليم متوسط \\
\hline \multirow[t]{2}{*}{9.2} & 19 & - ري بمياه عذبة & 9.2 & 19 & - نعليم جامعي \\
\hline & & 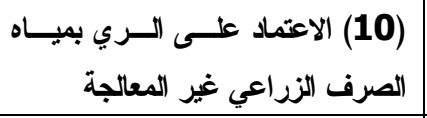 & & & بالزر (6) عدد أفراد الأسرة العـاملين \\
\hline 83.5 & 172 & - يعتمد عليها كل الوقت & 74.8 & 154 & - \\
\hline 15.5 & 34 & - يعتد عليها بعض الوقت & 20.9 & 43 & - - (3-4) فرد - \\
\hline 1.0 & 2 & - لا يعتمد عليها & 4.3 & 9 & - - (5-7) فرد - \\
\hline
\end{tabular}




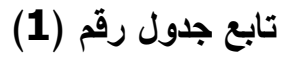

\begin{tabular}{|c|c|c|c|c|c|}
\hline$\%$ & عدد & المتغيـــــــر & $\%$ & عدد & المتغيـــــــر \\
\hline & & (14) حالة الصرف : & & & (11) موقع الأرض من مصدر الري : \\
\hline 44.6 & 92 & - سئــــــة & 30.6 & 63 & - - نهاية المسقى \\
\hline 29.7 & 60 & 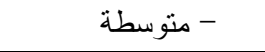 & 55.3 & 114 & - منتصف المسقى \\
\hline \multirow[t]{2}{*}{25.7} & 53 & 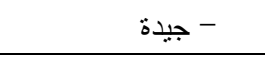 & 14.1 & 29 & - بـايــــــة المسقى \\
\hline & & (15) نوع التربة : & & & (12) نظام الري المستخدم : \\
\hline 70.8 & 146 & - - منأثرة بالأملاح & 58.7 & 121 & - غير مطور \\
\hline 20.9 & 43 & - طينيـــــــة & 41.3 & 85 & 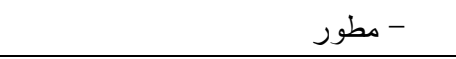 \\
\hline \multirow[t]{3}{*}{8.3} & 17 & - رمليــــــــــة & & & (13) نوعية المحاصيل المنزرعة : \\
\hline & & & 16.5 & 34 & - - محاصيل خضر \\
\hline & & & 83.5 & 172 & - محاصيل حقلية \\
\hline
\end{tabular}

$$
\begin{aligned}
& \text { جدول رقم (2) : توزيع قادة الر أى الزر اعيين المحليين المبحوثين وفقا لمستوى معرفتهم } \\
& \text { بأضر ار الرى بمياه الصرف الزر اعي غير المعالجة }
\end{aligned}
$$

\begin{tabular}{|c|c|c|}
\hline$\%$ & العـدد & فئات المستوى المعرفى \\
\hline صفر & صفر & منخفض (14- 23) درجة \\
\hline 21.4 & 44 & منوسط (24- 33) درجة \\
\hline 78.6 & 162 & مرتفع (34- 42) درجة \\
\hline 100,0 & 206 & المجمــوع \\
\hline
\end{tabular}


جدول رقم (3) : توزيع قادة الر أى الزر اعيين المحليين المبحوثين وفقا

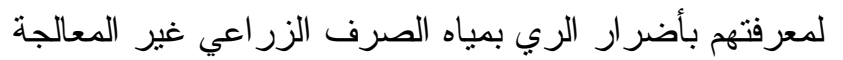

\begin{tabular}{|c|c|c|c|c|c|c|}
\hline \multicolumn{2}{|c|}{ ل لا يعرف } & \multicolumn{2}{|c|}{ يعرف لحد ما } & \multicolumn{2}{|c|}{ يعرف } & \multirow{2}{*}{ (الأضر ار) } \\
\hline$\%$ & عدد & $\%$ & عدد & $\%$ & عدد & \\
\hline- & - & 3.9 & 8 & 96.1 & 198 & 1- إصابة الإنسان بالأمر اض \\
\hline 2 & 4 & 9.7 & 20 & 88.3 & 182 & 2- انخفاض إنتاجية الدحاصيل \\
\hline- & - & 14.1 & 29 & 85.9 & 177 & 3- ظهور الأملاح على سطح التربة \\
\hline 5.3 & 11 & 18.9 & 39 & 75.7 & 156 & 4- 1 انتشار الحشائش \\
\hline 2.9 & 6 & 22.3 & 46 & 74.8 & 154 & 5- زيادة التكاليف متل الجبس الزراعي و السوبر فوسفات. \\
\hline- & - & 26.7 & 55 & 73.3 & 151 & 6- زيادة كميات المبيدات و الأسمدة الكيماوية \\
\hline 1.0 & 2 & 26.7 & 55 & 72.3 & 149 & 7- انتشار الحشر ات و الأمر اض \\
\hline 0.5 & 1 & 30.1 & 62 & 69.4 & 143 & 8- تطبيل التربة الزر اعية \\
\hline 2 & 4 & 33 & 68 & 65 & 134 & 9- ضعف نمو النباتات \\
\hline 24.8 & 50 & 17.4 & 37 & 57.8 & 119 & 10- إصـابة الحيو انات بالأمر اض \\
\hline 8.3 & 17 & 38.8 & 80 & 52.9 & 109 & 11 11 - نقزم النباتات \\
\hline 0.5 & 1 & 47.1 & 97 & 52.4 & 108 & 12- موت البادر ات \\
\hline 3.4 & 7 & 48.5 & 100 & 48.1 & 99 & 13- ظهور علامات العطش على النباتات \\
\hline 16.5 & 34 & 59.7 & 123 & 23.8 & 49 & 14- عدم استجابة التربة للذدمة أثناء الحرث \\
\hline
\end{tabular}

جدول رقم (4) : نوزيع قادة الر أى الزر اعيين المحليين المبحوثين وفقاً لمستوى معرفتهم بممارسات الحد من أضرار الري بمياه الصرف الزراعي فئرئ غير المعالجة

\begin{tabular}{|c|c|c|}
\hline$\%$ & العـدد & فئات المستوى المعرفى بالممارسات \\
\hline 5,82 & 12 & منخفض (21- 34) درجة \\
\hline 39,81 & 82 & متوسط (35- 49) درجة \\
\hline 54,37 & 112 & مرتفع (50- 63) درجة \\
\hline 100,0 & 206 & المجمــوع \\
\hline
\end{tabular}

الانحر اف المعيارى = 8,92 درجة 
جدول رقم (5) : توزيع قادة الر أى الزر اعيين المحليين المبحوثين وفقا لمعرفتهح

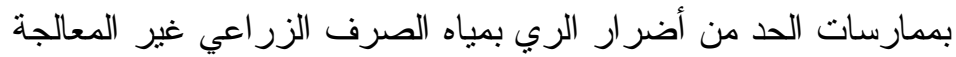

\begin{tabular}{|c|c|c|c|c|c|c|}
\hline \multicolumn{2}{|c|}{ ل لا يعرف } & \multicolumn{2}{|c|}{ يعرف لحد ما } & \multicolumn{2}{|c|}{ يعرف } & \multirow{2}{*}{ (الممارســـــات) } \\
\hline$\%$ & عدد & $\%$ & عدد & $\%$ & عدد & \\
\hline- & - & 7.3 & 15 & 92.7 & 191 & 1- التسوية الجيدة للأرض \\
\hline 3.9 & 8 & 5.3 & 11 & 90.8 & 197 & 2- الصرف الجيد للمحافظة على مستوى الماء الأرضي \\
\hline 0.4 & 10 & 14.6 & 31 & 85 & 175 & 3- استخدام المصلحات و والمحسنات مثل الجبس الزراعي \\
\hline 6.8 & 14 & 19.9 & 41 & 73.3 & 151 & 4- إنباع دورة زر اعية \\
\hline 17 & 35 & 18.9 & 39 & 64.1 & 132 & 5- اختيار الثقاوي ذات الجودة و النقاوة العالية \\
\hline 18 & 37 & 21 & 43 & 61 & 126 & 6- الري بالحو ال في المحاصيل التي تحتاج إلى ذلك \\
\hline 18 & 39 & 24.2 & 50 & 57.8 & 117 & 7- الزر اعة على خطوط \\
\hline 19.9 & 41 & 25.7 & 53 & 54.4 & 112 & 8- إتباع العمليات الزراعية المناسبة \\
\hline 20.4 & 42 & 34.5 & 71 & 45.2 & 93 & 9- استخدام الأسمدة و المبيدات بكميات مناسبة \\
\hline 20.9 & 43 & 36.9 & 76 & 42.2 & 87 & 10- زيادة كمية التقاوي عن المعدلات المعتادة \\
\hline 25.6 & 52 & 35.2 & 73 & 39.2 & 81 & 11- زر اعة الأصناف مبكرة النضج \\
\hline 25.7 & 53 & 35.9 & 74 & 38.4 & 79 & 12- الري بمياه صالحة مع مياه عذبة إذا أمكن \\
\hline 42.2 & 87 & 32.5 & 67 & 25.3 & 52 & 13- الري المتكرر على فترات متقاربة \\
\hline 42.7 & 88 & 33 & 68 & 24.3 & 50 & 14- نقع البذور لفترة معينة \\
\hline 44.2 & 91 & 33 & 68 & 22.8 & 47 & 15- تبطين ونطهير المساقي \\
\hline 45.2 & 93 & 34.5 & 71 & 20.3 & 42 & 16- عدم إلقاء حاويات المبيدات في الترع و المصارف \\
\hline 60.7 & 125 & 26.2 & 54 & 13.1 & 27 & 17- عدم شرب الحيو انات من مباه الصرف الزر اعي \\
\hline 70.4 & 146 & 19.4 & 40 & 10.2 & 21 & 18- اختبار المحاصيل و الأصناف المقاومة للملوحة \\
\hline 80.1 & 165 & 11.3 & 24 & 8.7 & 17 & 19- حقن التربة بالأمونيا \\
\hline 95.6 & 197 & 0.8 & 2 & 3.6 & 7 & 20- عمل أنفاق لتحسين الصرف وتقليل الملوحة \\
\hline 98.4 & 202 & 0.8 & 2 & 0.8 & 2 & 21- لبس قفاز ات للمتعاملين مع هذه المياه \\
\hline
\end{tabular}

جدول رقم (6) : وجهات نظر قادة الرأى الزراعيين المحليين المبحوثين فيما يجب أن يقوم به

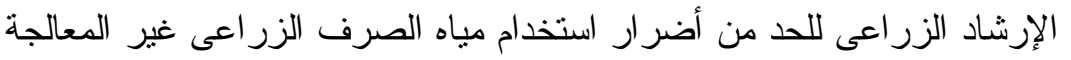

\begin{tabular}{|c|c|c|}
\hline$\%$ & العـدد & ما يجب أن يقوم به الإرشاد الزراعي \\
\hline 89.8 & 185 & 1- عقد دورات تدريبية لنو عية الزر اع بأضر ار الري بمياه الصرف الزر اعي \\
\hline 80.58 & 166 & 2- إدداد الزر اع بالمعلومات الكافية عن كيفية استعمال مياه الصرف الزر اعي \\
\hline 74.27 & 153 & 3- تعريف الزر اع بالمقتنات المائية للفدان من مياه الصرف الزر اعي \\
\hline 66.99 & 138 & 4- توفير الجبس الزر اعي للزر اع حتى بساعدهم على معالجة الأملاح \\
\hline 58.74 & 121 & 5- مساعدة الزر اع في عمل أنفاق بأرضهم لتحسين خواص التربة \\
\hline 48.06 & 99 & 6- نوفير الأجهزة و المعدات الزر اعية المختلفة في الوقت المناسب \\
\hline 45.14 & 93 & 7- توعية الزراع باستمر ار بأخطار الري بمياه الصرف الزراعي غير المعالج \\
\hline
\end{tabular}

